\title{
Palladacyclopentadienyl complexes bearing purine-based N-heterocyclic carbenes: A new class of promising antiproliferative agents against human ovarian cancer
}

\author{
Thomas Scattolin $^{1}$ | Sonia Giust ${ }^{1}$ | Paola Bergamini ${ }^{2}$ | Isabella Caligiuri $^{3}$ | \\ Luciano Canovese $^{1}$ (D) | Nicola Demitri ${ }^{4}$ (D) | Roberto Gambari $^{5}$ | Ilaria Lampronti ${ }^{5}$ | \\ Flavio Rizzolio ${ }^{1,3}$ | Fabiano Visentin ${ }^{1}$ (D)
}

\footnotetext{
${ }^{1}$ Dipartimento di Scienze Molecolari e Nanosistemi, Università Ca' Foscari, Campus Scientifico Via Torino 155, 30174 Venezia-Mestre, Italy

${ }^{2}$ Dipartimento di Scienze Chimiche e Farmaceutiche, Università degli Studi di Ferrara, Via Fossato di Mortara 74, 44121 Ferrara, Italy

${ }^{3}$ Pathology Unit, Department of Molecular Biology and Translational Research, National Cancer Institute and Center for Molecular Biomedicine - CRO, Aviano, Italy

${ }^{4}$ Elettra - Sincrotrone Trieste, SS $14 \mathrm{Km}$ 163.5 in Area Science Park, 34149, Basovizza, Trieste, Italy

${ }^{5}$ Dipartimento di Scienze della Vita e Biotecnologie, Università degli Studi di Ferrara, Via Fossato di Mortara 74, 44121 Ferrara, Italy
}

\section{Correspondence}

Fabiano Visentin, Dipartimento di Scienze Molecolari e Nanosistemi, Università Ca' Foscari, Campus Scientifico Via Torino 155, 30174 Venezia-Mestre, Italy.

Email: fvise@unive.it

Funding information

CIB (Consorzio Interuniversitario per le Biotecnologie); AIRC (Associazione Italiana Ricerca sul Cancro); University of Ferrara
A complete protocol for the synthesis of new palladacyclopentadienyl complexes with purine-based carbenes as supporting ligands is described. The new organometallic compounds were exhaustively characterized using NMR and infrared spectroscopies and elemental analysis. The single-crystal $\mathrm{X}$-ray structure of complex $\mathbf{2} \mathbf{b}$ coordinating also a triphenylphosphine was resolved. Some of these complexes showed an antiproliferative activity comparable to or better than that of cisplatin on two human ovarian cancer lines: A2780 (cisplatin-sensitive) and A2780cis (cisplatin-resistant). Moreover, for complexes $\mathbf{2}$ and $\mathbf{3}$ (coordinating one purine-based N-heterocyclic carbene ligand and one phosphine) the cytotoxicity is associated with an evident induction of apoptosis. Finally, complexes 3, bearing one purine-based $\mathrm{N}$-heterocyclic carbene ligand and one 1,3,5-triaza-7-phosphaadamantane, proved practically inactive on non-tumour fibroblast cells (MRC-5).

\section{KEYWORDS}

antiproliferative and pro-apoptotic activity, $\mathrm{N}$-heterocyclic carbenes, ovarian cancer, palladacyclopentadienyl complexes, purine bases

\section{1 | INTRODUCTION}

In recent years a number of different platinum complexes have been synthesized with the aim of reproducing, or possibly enhancing, the therapeutic properties of cisplatin and its analogues of second and third generation. ${ }^{[1,2]}$ It is worth noting that such compounds still represent the most widely used chemotherapeutic metallodrugs active in the battle against neoplastic pathologies despite the resistance mechanism developed by some 
typology of neoplasia, ${ }^{[3]}$ their remarkable toxicity and their reduced versatility towards several tumours. On the other hand, the development of synthetic analogues might be of great interest in lowering the toxicity or implementing the multidrug approach to cancer therapy. Moreover, the multiplicity of possible cellular targets and/or the difficulty of predicting the mechanism of interaction with biomolecules mean that it is very demanding to plan on paper the structure and features of a new metal chemotherapeutic drug.

Therefore, no impressive improvements have been obtained so far. ${ }^{[4]}$ One alternative approach to the problem is based on investigating systematically unexplored classes of metal compounds. The possibility of choosing ancillary ligands and organometallic fragments offers many variables, from a combination of which might emerge a new effective chemotherapeutic drug. ${ }^{[5,6]}$

In this respect, palladium might represent a valid alternative to platinum because of the similarity among the structures of their complexes. On the other hand, palladium derivatives show a better solubility in water and a markedly enhanced reactivity with respect to those of platinum. ${ }^{[7,8]}$ In this context, it was recently shown that palladium complexes stabilized by strong ligands often display a higher anticancer activity than the usual platinum agents. ${ }^{[9]}$

On the basis of such observations, we have recently carried out a study describing the synthesis of several allyl palladium complexes stabilized by various $\mathrm{N}$-heterocyclic carbene (NHC) spectator ligands derived from three appropriately functionalized methylxanthines ${ }^{[10]}$ which show an antiproliferative activity, in many cases markedly higher than that of the reference cisplatin. ${ }^{11 a}$ We have planned this sort of investigation accepting some literature suggestions. Firstly, we supposed that the easier dissociation path in bloodstream and/or cellular environment of palladium complexes compared to platinum derivatives $^{8 \mathrm{~b}, \mathrm{c}}$ could be reduced by strong stabilizing NHC ligands. ${ }^{[12]}$ In this respect it is worth noting that some NHC-palladium derivatives described in the
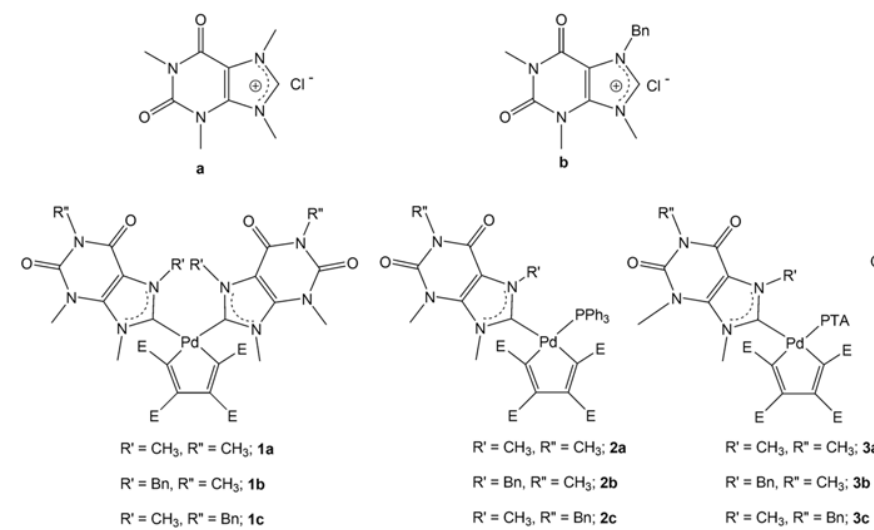

literature display reduced cytotoxicity ${ }^{[9 \mathrm{a}, \mathrm{d}, 13]}$ and a noticeable cancer growth suppression in vivo. ${ }^{\left[{ }^{[9,12 e]}\right.}$ Secondly, the natural origin of xanthines suggested a possible increased compatibility and therefore an enhanced interaction of the related derivatives with the biological environment, as already shown elsewhere. ${ }^{[14]}$

In the work presented here and at variance with previous work focused on the palladium-allyl moiety, ${ }^{11 a}$ we opted for the palladacyclopentadienyl group since it was shown that palladacycles can be very effective against various cancer cell lines. ${ }^{9 \mathrm{~d}}$ Moreover, the experience we developed on these substrates ${ }^{[15]}$ suggests that this organometallic fragment should remain stable in a biological environment.

As supporting ligands, in addition to purine-based NHCs, we chose triphenylphosphine $\left(\mathrm{PPh}_{3}\right)$, 2,6-dimethylphenylisocyanide (DIC) and 1,3,5-triaza-7-phosphadamantane (PTA), with the aim of obtaining complexes with different steric and electronic features. In particular, it is well known that PTA can increase the water solubility of its derivatives. ${ }^{[16]}$

The structures of the palladacyclopentadienyl derivatives synthesized and tested against the A2780 (cisplatinsensitive) and A2780cis (cisplatin-resistant) cancer lines are reported in Scheme 1.

\section{2 | RESULTS AND DISCUSSION}

\section{1 | Synthesis of purine-based imidazolium salts}

Compounds a-c were obtained pure and in quantitative yields by metathesis of tetrafluoroborate ions with tetraphenylarsonium chloride of alkylated xanthines, synthesized according to methods published elsewhere ${ }^{[11]}$ (Figure S1a, supporting information).

The chloride derivatives were characterized using ${ }^{1} \mathrm{H}$ NMR and ${ }^{13} \mathrm{C}$ NMR spectroscopy and the spectra of compounds a-c display slight modification with respect to
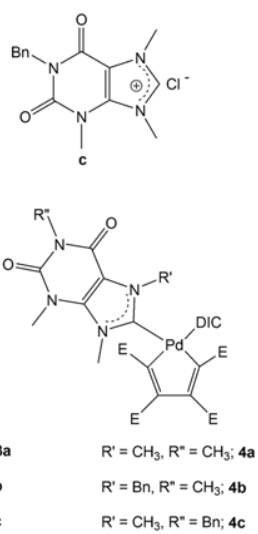

SCHEME 1 Starting imidazolium salts (a-c) and palladacyclopentadienyl derivatives (1-4) 
those of the original tetrafluoroborate derivatives (Figure S1b-g, supporting information). In particular, the marked downfield shift (ca $1.5 \mathrm{ppm}$ ) of the barely significant imidazolic proton is worth noting.

\section{2 | Synthesis of silver purine-based NHC complexes}

The reaction of compounds a-c with $\mathrm{Ag}_{2} \mathrm{O}$ carried out in $\mathrm{CH}_{3} \mathrm{CN}$ for $4 \mathrm{~h}$ in the dark yielded the silver complexes Aga-c (Scheme 2).

A comparison between the NMR spectra of the starting alkylated xanthines and the ensuing silver complexes confirms that the reaction summarized in Scheme 2 took place. As can be seen (Figure S2a-d,g-j, supporting information), the peak of the imidazole proton disappears and all the signals belonging to alkyl and aryl groups undergo a shift upon coordination with the metal. The complete assignment of the signals has been carried out on the basis of the two-dimensional HSQC and HMBC NMR spectra. However, the true molecular structure of complexes Aga-c was assigned by means of ESI-MS, which indicates that the carbene silver complexes, according to the suggestion of Nolan and co-workers, ${ }^{[17]}$ are better described as $[(\mathrm{NHC}) \mathrm{Ag}(\mathrm{NHC})]\left[\mathrm{AgCl}_{2}\right]$ rather than the simpler $[(\mathrm{NHC}) \mathrm{Ag}(\mathrm{NHC})] \mathrm{Cl}$ (Figure $\mathrm{S} 2 \mathrm{e}, \mathrm{f}$, supporting information).

\section{3 | Synthesis of bis-NHC palladacyclopentadienyl complexes}

The synthesis of the title complexes was carried out according to Scheme 3. Complexes 1 were synthesized by reacting compounds Aga-c and the polymeric

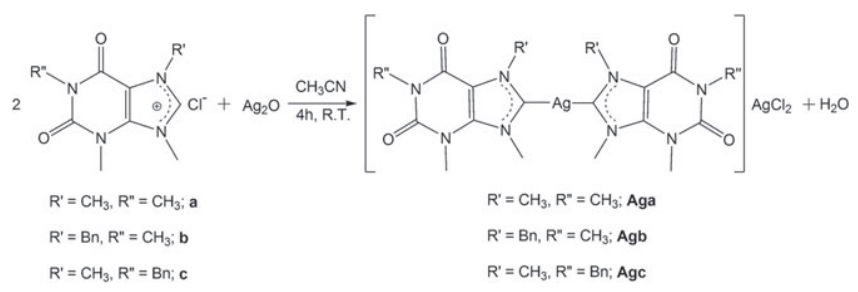

SCHEME 2 Synthesis of silver purine-based NHC complexes precursor $\left[\mathrm{PdC}_{4}\left(\mathrm{COOCH}_{3}\right)\right]_{n}$. The synthesis was conducted according to published methods. ${ }^{[11,18]}$ Despite the difficulty we have hitherto faced when bulky carbenes are used for the preparation of bis-carbene complexes, ${ }^{15 e}$ the synthesis of derivatives $\mathbf{1}$ proceeded without particular problems and they were obtained in reasonable yields.

The NMR spectra, however, are characterized by the doubling of all the signals ascribable to the synthesized complexes, as can be noticed in Figure 1 and Figure S3 (supporting information). In the case of complexes $\mathbf{1 c}$ (Figure 1) and $\mathbf{1 b}$, an $\mathrm{AB}$ system, due to the presence of two non-equivalent $\mathrm{CH}_{2} \mathrm{Ph}$ groups, together with the already cited doubling of all the other signals, strongly suggest the concomitant and essentially equimolecular formation of two atropoisomers in which the benzyl fragments lie on the same or opposite side of the main plane of the complexes owing to the hindered rotation about the $\mathrm{Pd}-\mathrm{C}$ bond of the non-symmetric carbene (Figure 2).

The detailed ${ }^{1} \mathrm{H}$ NMR and ${ }^{13} \mathrm{C}$ NMR investigations, supported by HSQC and HMBC spectra (Figure S3, supporting information), confirm the structure in solution of complexes $\mathbf{1}$. In particular:

i) the carbenic $\mathrm{NCH}_{3}$ groups of any atropoisomer resonate at chemical shifts different from those of the silver complexes.

ii) Two different couple of signals for the $\mathrm{OCH}_{3}$ groups in both the ${ }^{1} \mathrm{H}$ NMR and ${ }^{13} \mathrm{C}$ NMR spectra are detected.

iii) The already cited $\mathrm{AB}$ signal ascribable to the $\mathrm{CH}_{2} \mathrm{Ph}$ benzyl protons in the case of complexes $\mathbf{1 b}$ and $\mathbf{1 c}$ is observed.

iv) Two different carbene carbon signals are observed at ca 188 ppm.

\section{4 | Synthesis of mixed $\mathrm{NHC}-\mathrm{PPh}_{3}$ palladacyclopentadienyl complexes (2)}

As a consequence of a detailed study entailing theoretical approaches and experimental controls, ${ }^{[20]}$ we were able to prepare pure complexes 2 using the non-conventional synthetic methodology reported in Scheme 4. This

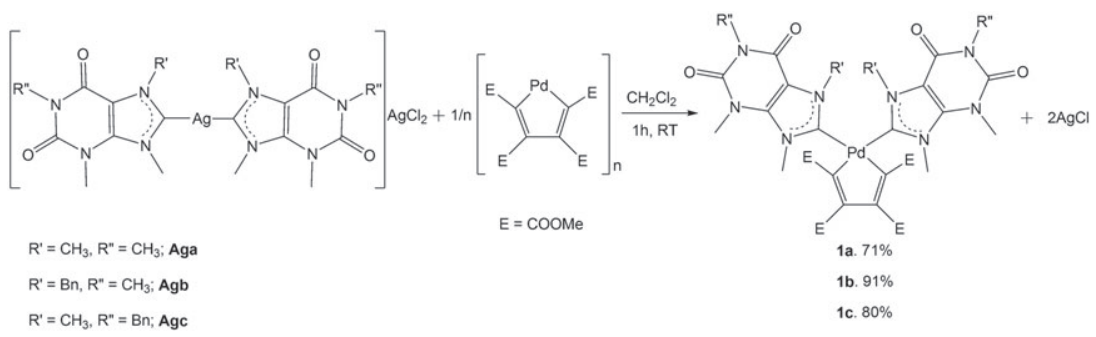



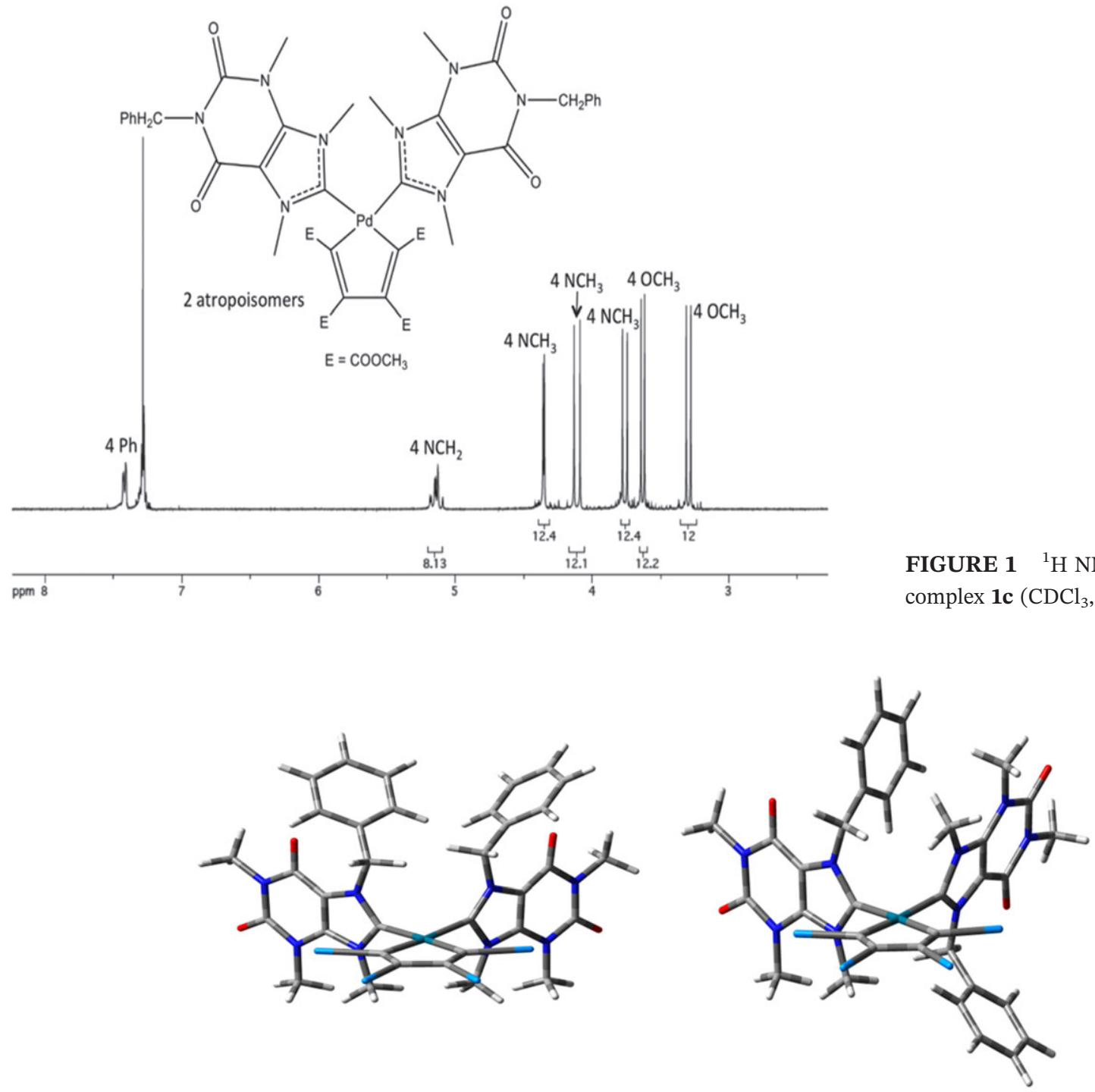

FIGURE 2 Density functional theory representation ${ }^{[19]}$ of the atropoisomers of complex $\mathbf{1 b}$ (for the sake of optimization of computer time, the COOMe group was substituted with the less disordered $\mathrm{CN}$ )

methodology does not always lead to the formation of the mixed complexes since well-defined thermodynamic and kinetic conditions must be obeyed in order to avoid the formation of the bis-carbene and bis-phosphino complexes only, or a mixture of all the possible derivatives. A preliminary density functional theory study of the thermodynamic stability of the involved species ${ }^{[19]}$ (Figure S4, supporting information) and consequent experimental results show
FIGURE $1{ }^{1} \mathrm{H}$ NMR spectrum of complex 1c $\left(\mathrm{CDCl}_{3}, T=298 \mathrm{~K}\right)$

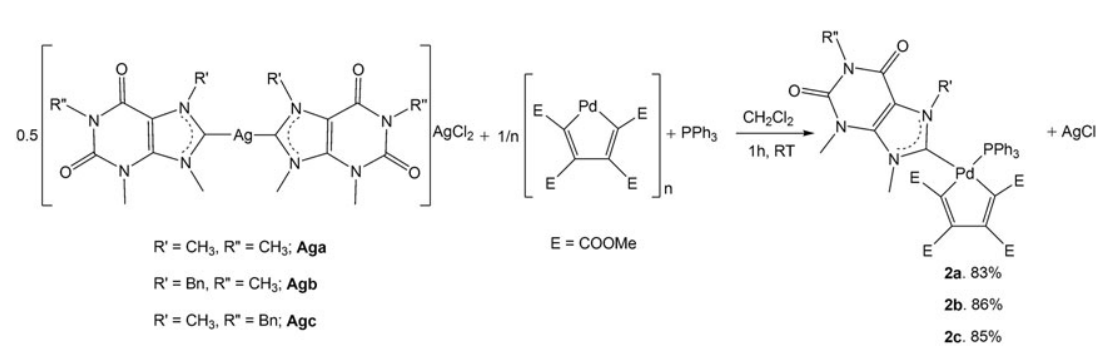

that in this and in other cases (discussed below) the preconditions elsewhere identified ${ }^{[20]}$ have been satisfied.

The characterization of complexes 2 was carried out using NMR and infrared (IR) spectroscopies (Figures S5, supporting information) and in the case of complex $\mathbf{2 b}$ by the diffractometric resolution of its solid-state structure.

The ${ }^{31} \mathrm{P}\left\{{ }^{1} \mathrm{H}\right\}$ NMR spectra of the complexes show a single signal at ca 25-26 ppm at lower field than that of free 
$\mathrm{PPh}_{3}$ (ca $30 \mathrm{ppm}$ ) (Figure S5a, supporting information). Due to the asymmetry induced by the different spectator ligands, the ${ }^{1} \mathrm{H}$ NMR and ${ }^{13} \mathrm{C}$ NMR spectra of all the complexes show four signals related to the COOMe groups (Figure S5b,c,g-j, supporting information).

In the ${ }^{1} \mathrm{H}$ NMR spectra, all the $\mathrm{NCH}_{3}$ protons are clearly detectable whereas those belonging to the $\mathrm{CH}_{2} \mathrm{Ph}$ groups in the case of complexes $\mathbf{2 b}$ and $\mathbf{2 c}$ resonate as $\mathrm{AB}$ systems owing to their magnetic non-equivalence induced by the hindered rotation of the carbene about the $\mathrm{Pd}-\mathrm{C}$ bond. Finally, the carbene carbon resonates as a doublet at $c a$ 190 ppm owing to the coupling with vicinal phosphorus.

As a definitive confirmation of the steric nature of these complexes, we show in Figure 3 the resolved solidstate structure of complex $\mathbf{2} \mathbf{b}$ which will be discussed later on. Other ORTEP ${ }^{[21]}$ representations of complex $\mathbf{2 b}$ are shown in Figure S8 (supporting information).

\section{5 | Synthesis of mixed NHC-PTA palladacyclopentadienyl complexes (3)}

As can be seen in Scheme 5, also in this case the thermodynamic and kinetic conditions yielding these complexes bv direct svnthesis were fulfilled.

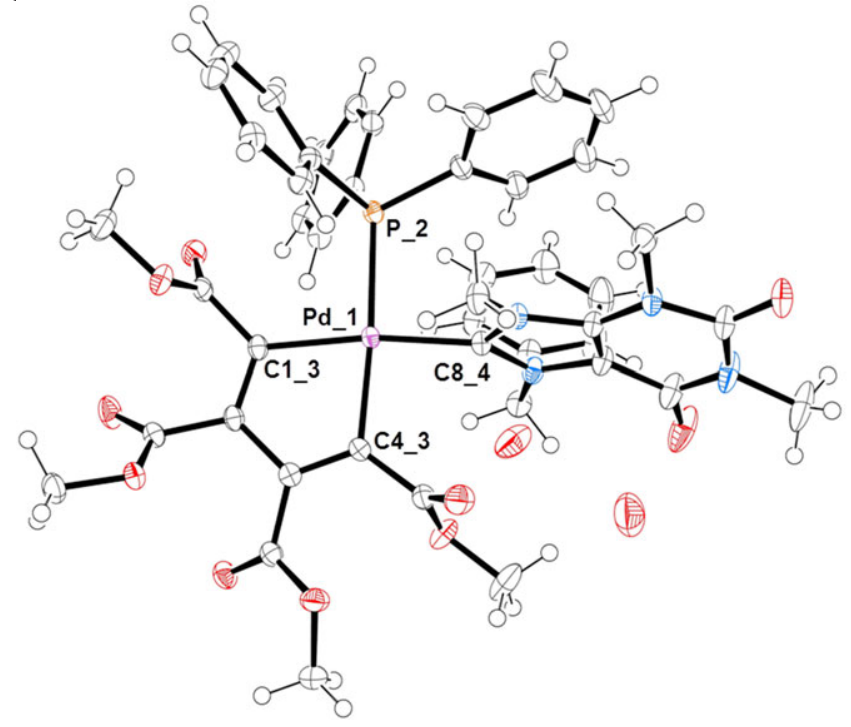

FIGURE 3 Ellipsoid representation of $\mathbf{2 b}$ crystal ASU contents (50\% probability)
The NMR investigations confirm the nature of the title derivatives and the related NMR and IR spectra are shown in Figure S6 (supporting information). Thus, in the ${ }^{1} \mathrm{H}$ NMR investigation, the singlets ascribable to the $\mathrm{NCH}_{3}$ groups belonging to all the complexes and the $\mathrm{AB}$ systems of the $\mathrm{NCH}_{2}$ fragments of complexes $\mathbf{3 b}$ and $\mathbf{3} \mathbf{c}$ are detected in the range $3.40-4.20$ and $5.00-6.50 \mathrm{ppm}$, respectively. The $\mathrm{NCH}_{2} \mathrm{~N}$ and $\mathrm{NCH}_{2} \mathrm{P}$ protons of the coordinated PTA resonate in the range 4.30-4.50 and 3.50-4.00 ppm, respectively, whereas the four $\mathrm{OCH}_{3}$ groups are observed between 3.2 and $3.8 \mathrm{ppm}$.

In the ${ }^{13} \mathrm{C}\left\{{ }^{1} \mathrm{H}\right\} \mathrm{NMR}$ spectra, the carbene carbon resonates in the range $180-190 \mathrm{ppm}$ as a doublet $\left(J_{\mathrm{C}-}\right.$ $\mathrm{P} \approx 17-18 \mathrm{~Hz}$ ) whereas $\mathrm{NCH}_{2} \mathrm{P}$ and $\mathrm{NCH}_{2} \mathrm{~N}$ are detected at ca $50 \mathrm{ppm}$ (doublet, $J_{\mathrm{C}-\mathrm{P}} \approx 10 \mathrm{~Hz}$ ) and $73 \mathrm{ppm}$ (doublet, $\left.J_{\mathrm{C}-\mathrm{P}} \approx 6 \mathrm{~Hz}\right)$, respectively.

\section{6 | Synthesis of mixed NHC-DIC complexes (4)}

Despite the electronic difference between the good $\pi$-acceptor DIC and the other ligands used in this research, which are all $\sigma$-donating molecules although to different degrees, the synthetic protocol yielding complexes $\mathbf{4}$ remains almost the same as those previously described (Scheme 6). As a matter of fact, the most relevant difference between the protocols is the reaction rate, which in this case is considerably lower ( $48 \mathrm{~h}$ ) than those related to the formation of complexes 1-3 (1 h). Moreover, soon after the mixing of the reagents, three complexes, namely the bis-substituted isocyanide, bis-substituted carbene and mixed palladacyclopentadienyl derivative $\mathbf{4}$, are detected in solution. These kinds of reaction are not unprecedented and have been recently studied in detail. ${ }^{[20]}$ Eventually, the thermodynamically stable mixed species $\mathbf{4}$ were exhaustively formed and the long time necessary for the completion of the reaction is mainly due to the steric hindrance induced by the bulky homogeneously substituted biscarbene and bi-isocyanide palladacyclopentadienyl complexes reacting with each other. ${ }^{[22]}$

The characterization of complexes $\mathbf{4}$ was carried out using NMR and IR spectroscopies and the related spectra are reported in the supporting information (Figure S7a-i).

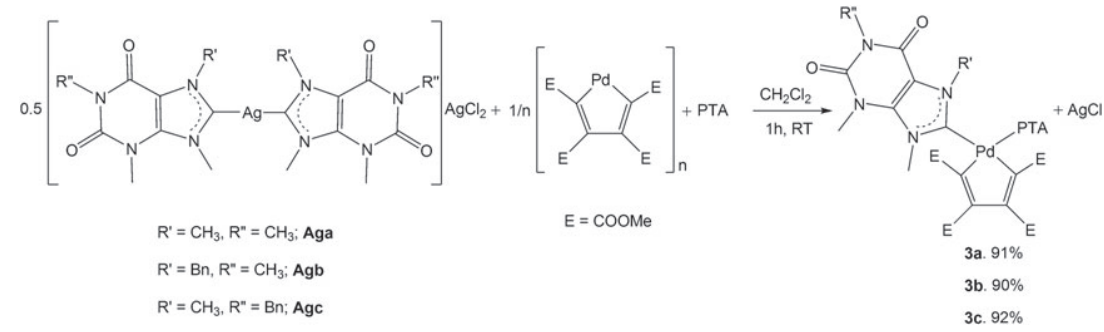




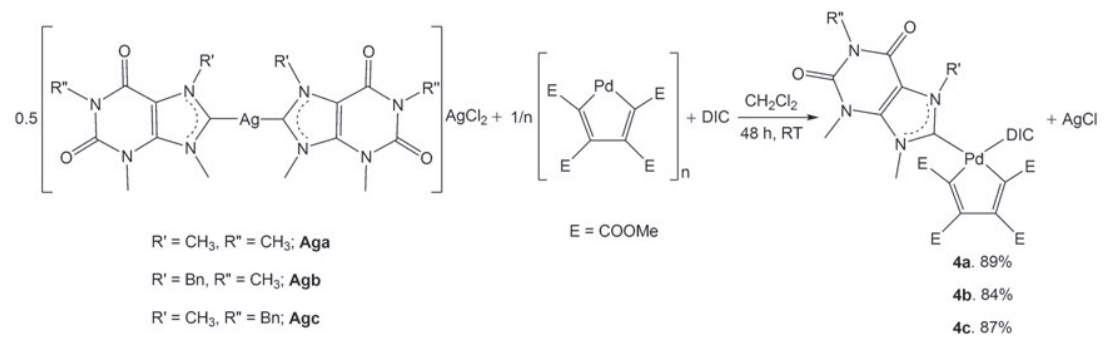

SCHEME 6 Synthesis of complexes 4

In particular, in the ${ }^{1} \mathrm{H}$ NMR spectra, the purinic $\mathrm{NCH}_{3}$ groups are observed as singlets in the range 3.35-4.35 ppm, whereas in the case of complexes $\mathbf{4 b}$ and $4 \mathbf{c}$ the $\mathrm{AB}$ systems of the benzyl $\mathrm{NCH}_{2}$ protons are detected in the range 5.10-6.00 ppm. The four $\mathrm{OCH}_{3}$ fragments resonate in the range $3.29-3.81 \mathrm{ppm}$ whereas the isocyanide methyl groups, at variance with those of the free moiety, are observed as singlets in the range 2.00-2.50 ppm.

In the ${ }^{13} \mathrm{C}\left\{{ }^{1} \mathrm{H}\right\} \mathrm{NMR}$ spectra, the isocyanide and the carbene carbons are easily observed at $c a 149$ and in the range 180-190 ppm, respectively.

\section{7 | X-ray diffraction analysis: structural characterization of $\mathbf{2 b}$}

The crystalline form of $\mathbf{2 b}$ contains one crystallographically independent palladium complex (Figure 3). Palladium centres adopt square planar coordination spheres with bond lengths and angles (Table 1) in agreement with literature structural data of complexes with similar ligands. The CSD database (version 5.39 - November 2017) reports only one alternative Pd (II)-xanthine complex showing compatible $\mathrm{Pd}-\mathrm{C}$ bond length (2.008(14) $\AA$ ). ${ }^{[23]}$ Furthermore, the molecular model of $\mathbf{2 b}$ is well superimposable with the related (2,6-dimethylphenylisocyanide)-(1,2,3,4-tetrakis(methoxycarbonyl)buta-1,3-d iene-1,4-diyl)-(triphenylphosphine)palladium structure (green sticks; CCDC no. 825712) complex ${ }^{[24]}$ (CCDC no. 714135); RMSD of common atoms shared by the two models is $0.81 \AA$ (Figure S9, supporting information).

The structure of $\mathbf{2} \mathbf{b}$ shows that the xanthine minimizes steric repulsions in the solid state, adopting a roughly

TABLE 1 Selected bond distances and angles for the palladium coordination sphere of 2b. Naming schemes are reported in Figure 3

\begin{tabular}{llll} 
Bond & Length $(\AA)$ & Angle & Value $\left(^{\circ}\right)$ \\
\hline Pd_1-C1_3 & $2.0757(17)$ & C1_3-Pd_1-C4_3 & $80.08(7)$ \\
\hline Pd_1-C4_3 & $2.0647(18)$ & C1_3-Pd_1-P_2 & $95.81(5)$ \\
\hline Pd_1-P_2 & $2.3367(8)$ & P_2-Pd_1-C8_4 & $92.83(5)$ \\
\hline Pd_1-C8_4 & 2.0379(17) & C8_4-Pd_1-C4_3 & $91.21(7)$ \\
\hline
\end{tabular}

perpendicular orientation with respect to the palladium coordination plane $\left(69.48^{\circ}\right.$ in $\left.\mathbf{2 b}\right)$. Neighbour ligand sidechains (a phenyl from the phosphine and one carbomethoxy from the buta-1,3-diene-1,4-diyl ligand) adopt conformations parallel to the xanthine, with average plane distances of 3.1(5) $\AA$ suggesting that $\pi \cdots \pi$ interligand contacts might stabilize the complex. Crystal packing shows hydrophobic contacts among neighbour molecules, involving several $\mathrm{CH} \cdots \pi$ and minor $\pi \cdots \pi$ interactions, while water molecules are trapped in polar cavities where hydrogen bonds link carbomethoxy groups of neighbour palladium complexes.

\section{8 | Antiproliferative activity}

The complexes containing PTA (3a-c) are very soluble in water. All other complexes are scarcely soluble in water, and for this reason the stock solutions $(50 \mathrm{mM})$ for

TABLE 2 Effects of complexes on proliferation of A2780 and A2780cis cells. The inhibition of cell growth is represented as $\mathrm{IC}_{50}$. DMSO stock solutions (50 mM) of the complexes were diluted with $\mathrm{EtOH}$ to obtain working solutions. Cisplatin was dissolved in water

\begin{tabular}{lcc} 
& \multicolumn{1}{c}{$\mathbf{I C}_{\mathbf{5 0}}(\boldsymbol{\mu} \mathbf{M})$} & \\
\cline { 2 - 3 } Complex & $\mathbf{A 2 7 8 0}\left(\mathbf{I C}_{\mathbf{5 0}}\right)$ & $\mathbf{A 2 7 8 0} \mathbf{c i s}\left(\mathbf{I C}_{\mathbf{5 0}}\right)$ \\
Cisplatin & $0.6 \pm 0.1$ & $6 \pm 1$ \\
{$\left[\mathrm{PdC}_{4}\left(\mathrm{COOCH}_{3}\right)_{4}\right]_{n}$} & $>100$ & $>100$ \\
\hline $\mathbf{1 a}$ & $9.0 \pm 0.7$ & $7.03 \pm 0.01$ \\
\hline $\mathbf{1 b}$ & $6.5 \pm 0.5$ & $5.53 \pm 0.06$ \\
\hline $\mathbf{1 c}$ & $81 \pm 4$ & $60 \pm 3$ \\
\hline 2a & $5.3 \pm 0.7$ & $6.7 \pm 0.8$ \\
\hline 2b & $5.0 \pm 0.2$ & $5.25 \pm 0.05$ \\
\hline 2c & $6.66 \pm 0.03$ & $16 \pm 1$ \\
\hline 3a & $4.3 \pm 0.7$ & $0.65 \pm 0.2$ \\
\hline 3b & $0.9 \pm 0.1$ & $1.0 \pm 0.3$ \\
\hline 3c & $0.56 \pm 0.08$ & $0.62 \pm 0.07$ \\
\hline 4a & $3.3 \pm 0.6$ & $2.1 \pm 0.4$ \\
\hline 4b & $1.6 \pm 0.3$ & $1.8 \pm 0.9$ \\
\hline 4c & $0.7 \pm 0.05$ & $0.87 \pm 0.09$ \\
\hline
\end{tabular}


biological investigations were prepared in dimethylsulfoxide (DMSO) and the working solutions were then obtained by dilution with ethanol.

The stability of the complexes was preliminarily checked in $\mathrm{D}_{2} \mathrm{O}$ (3) or DMSO- $d_{6}(\mathbf{1}, 2$ and 4): after $48 \mathrm{~h}$ at room temperature no ligand replacement and no degradation were observed. The ability of all the synthesized complexes in inhibiting the cell proliferation of ovarian cancer cells A2780 and A2780cis was analysed after $72 \mathrm{~h}$ treatment, in order to explore their biological activity in comparison with cisplatin, a known antineoplastic agent. The two cell lines exhibited a sharply different response to cisplatin exposure. One (A2780) was sensitive to cisplatin, while the other (A2780cis) was

TABLE 3 Effects of complexes on proliferation of MRC-5 human fibroblasts. The inhibition of cell growth is represented as $\mathrm{IC}_{50}$. DMSO stock solutions (50 mM) of the complexes were diluted with $\mathrm{EtOH}$ to obtain working solutions. Cisplatin was dissolved in water

\begin{tabular}{ll} 
Complex & IC $_{\mathbf{5 0}}(\boldsymbol{\mu M})$ \\
\hline Cisplatin & $14 \pm 1$ \\
\hline 2b & $30 \pm 15$ \\
\hline 3c & $>100$ \\
\hline
\end{tabular}

cisplatin resistant. In Table 2, the results obtained from three independent experiments are reported. The strong antiproliferative activity of cisplatin $\left(\mathrm{IC}_{50}=0.6 \pm 0.1 \mu \mathrm{M}\right)$ on the A2780 cell line was confirmed; ${ }^{[11,25]}$ in addition, the obtained data confirmed the cisplatin resistance of the A2780cis cell line $\left(\mathrm{IC}_{50}=6 \pm 1 \mu \mathrm{M}\right)$. For all the complexes investigated, with the exception of $\mathbf{2 c}$, the $\mathrm{IC}_{50}$ values against the $\mathrm{A} 2780$ and A2780cis cell lines were similar, indicating that they were active also on the resistant cell line. Notably, compound 3a exhibited higher activity on A2780cis cells with respect to A2780 cells. The compounds exhibiting the highest in vitro antiproliferative activity $\left(\mathrm{IC}_{50} \leq 1 \mu \mathrm{M}\right)$ were $\mathbf{3 a}, \mathbf{3 b}, \mathbf{3} \mathbf{c}$ and 4c. All these compounds displayed a very interesting ability in inducing cytotoxicity in both the cell lines, featuring higher activity than cisplatin against the resistant cells.

In order to preliminarily evaluate a potential selectivity of the palladacyclopentadienyl complexes against cancer cells, normal human fibroblasts (MRC-5) were treated for $72 \mathrm{~h}$ with complexes $\mathbf{2 b}$ and the most effective $\mathbf{3 c}$. As evident from Table 3, the compounds are poorly active (2b) or inactive (3c) against this non-tumour cell line, suggesting a preferential activity of the analysed compounds against cancer cells.

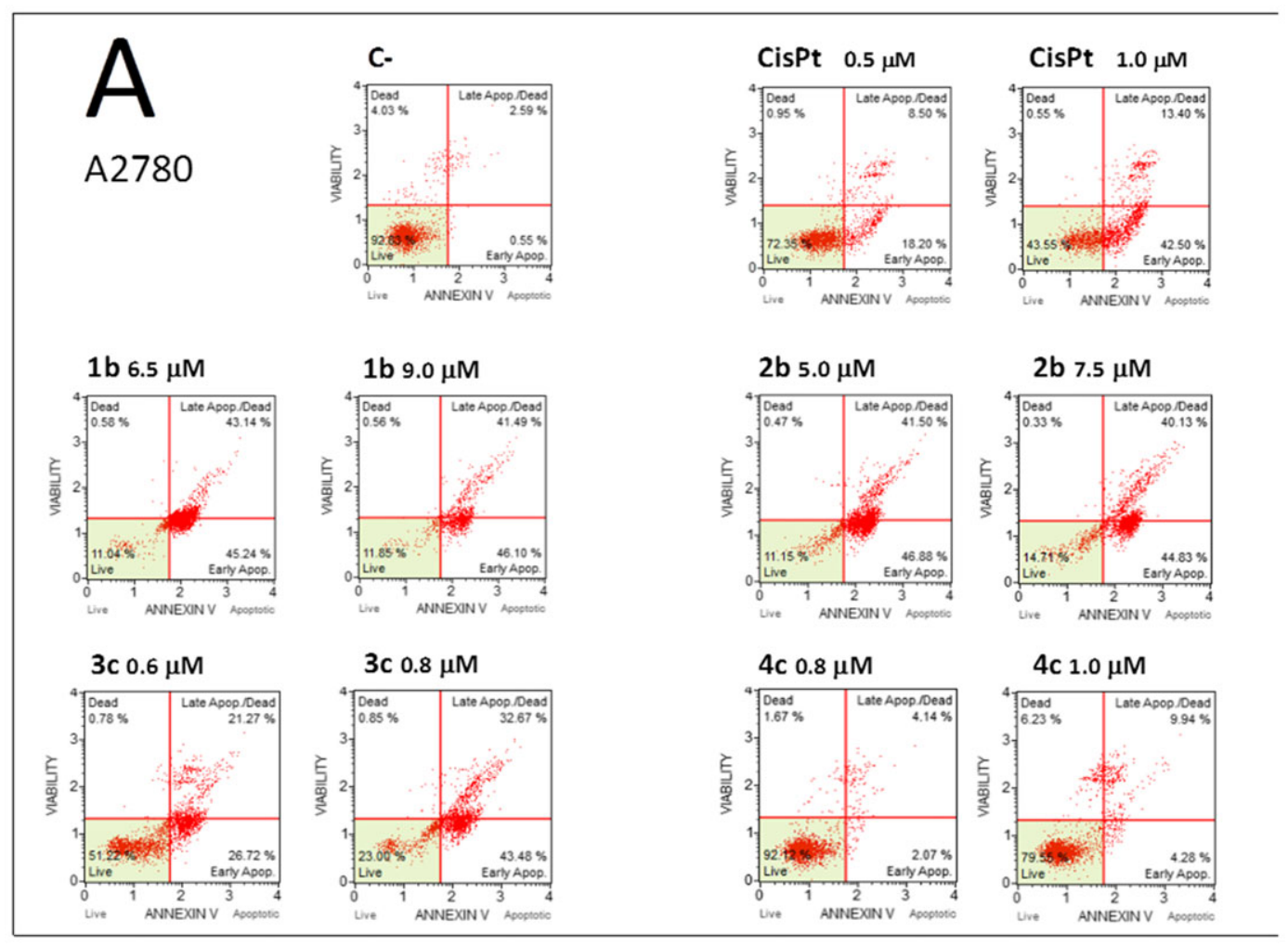

FIGURE 4 Representative apoptosis profiles of A2780 cells untreated $(\mathrm{C}-)$, treated for $72 \mathrm{~h}$ with cisplatin $(\mathrm{C}+; 0.5$ and $1.0 \mu \mathrm{M})$ and treated with complexes $\mathbf{1 b}, \mathbf{2 b}, \mathbf{3 c}$ and $\mathbf{4 c}$ at various concentrations ( $\mathrm{IC}_{50}$ and $\mathrm{IC}_{75}$ values). DMSO stock solutions (50 $\mathrm{mM}$ ) of the complexes were diluted with ethanol to obtain working solutions. Cisplatin was dissolved in water 


\section{9 | Pro-apoptotic effects}

In order to verify whether the antiproliferative activity of the newly synthesized compounds is associated with the activation of the apoptotic pathway (as is known when cisplatin is administered to tumour cells of various origins), ${ }^{[26-29]}$ the complexes of each series demonstrating the best antiproliferative activity $(\mathbf{1} \mathbf{b}, \mathbf{2 b}, \mathbf{3 c}, \mathbf{4 c})$ were investigated. The Annexin $\mathrm{V}$ test and a MUSE cell analyser were employed for this purpose. Representative results are shown in Figures 4 and 5, and all the obtained data are summarized in Table 4. All the selected derivatives, with the exception of $\mathbf{4 c}$, induced evident apoptosis in both cell lines. These assays have been performed

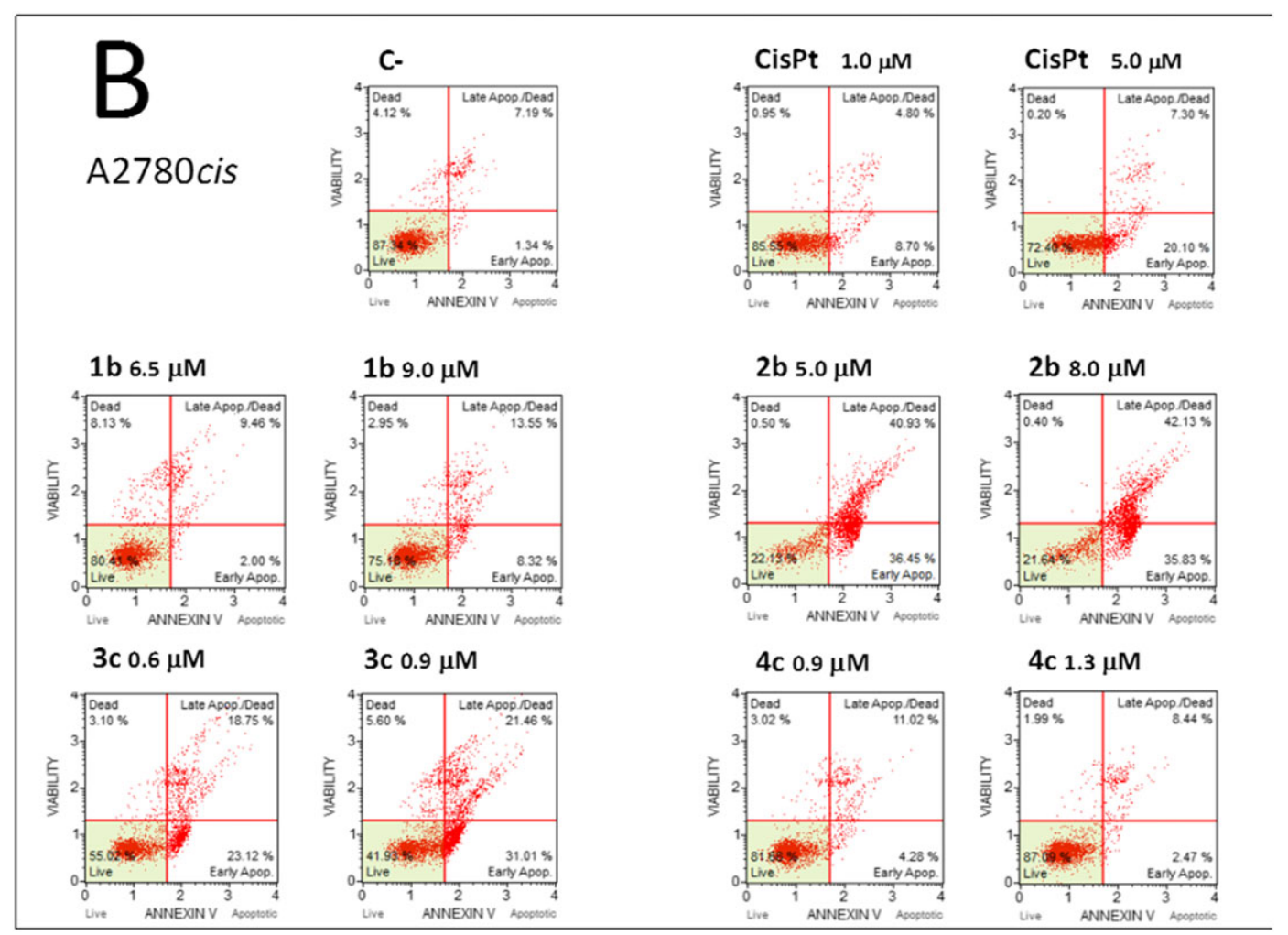

FIGURE 5 Representative apoptosis profiles of A2780cis cells untreated (C-), treated for $72 \mathrm{~h}$ with cisplatin $(\mathrm{C}+; 1.0$ and $5.0 \mu \mathrm{M})$ and treated with complexes $\mathbf{1 b}, \mathbf{2} \mathbf{b}, \mathbf{3} \mathbf{c}$ and $\mathbf{4 c}$ at various concentrations ( $\mathrm{IC}_{50}$ and $\mathrm{IC}_{75}$ values). DMSO stock solutions (50 mM) of the complexes were diluted with ethanol to obtain working solutions. Cisplatin was dissolved in water

TABLE 4 Pro-apoptotic effects of complexes on A2780 and A2780cis cell lines detected at two concentrations. (C-, untreated cells). DMSO stock solutions $(50 \mathrm{mM})$ of the complexes were diluted with EtOH to obtain working solutions. Cisplatin was dissolved in water

\begin{tabular}{|c|c|c|c|c|}
\hline Complex & $\begin{array}{l}\text { Total apoptosis (\%) } \\
\text { A2780 }\end{array}$ & $\begin{array}{l}\text { Dead cells (\%) } \\
\text { A2780 }\end{array}$ & $\begin{array}{l}\text { Total apoptosis (\%) } \\
\text { A2780cis }\end{array}$ & $\begin{array}{l}\text { Dead cells (\%) } \\
\text { A2780cis }\end{array}$ \\
\hline $\mathrm{C}-$ & 3.14 & 4.03 & 8.53 & 4.12 \\
\hline $1 b$ & $\begin{array}{l}88.38(6.5 \mu \mathrm{M}) \\
87.59(9.0 \mu \mathrm{M})\end{array}$ & $\begin{array}{l}0.58(6.5 \mu \mathrm{M}) \\
0.56(9.0 \mu \mathrm{M})\end{array}$ & $\begin{array}{l}11.46(5.5 \mu \mathrm{M}) \\
21.87(8.5 \mu \mathrm{M})\end{array}$ & $\begin{array}{l}8.13(5.5 \mu \mathrm{M}) \\
2.95(8.5 \mu \mathrm{M})\end{array}$ \\
\hline $2 b$ & $\begin{array}{l}88.38(5.0 \mu \mathrm{M}) \\
84.96(7.5 \mu \mathrm{M})\end{array}$ & $\begin{array}{l}0.47(5.0 \mu \mathrm{M}) \\
0.33(7.5 \mu \mathrm{M})\end{array}$ & $\begin{array}{l}77.38(5 \mu \mathrm{M}) \\
77.96(8 \mu \mathrm{M})\end{array}$ & $\begin{array}{l}0.50(5 \mu \mathrm{M}) \\
0.40(8 \mu \mathrm{M})\end{array}$ \\
\hline $3 c$ & $\begin{array}{l}47.99(0.6 \mu \mathrm{M}) \\
76.15(0.8 \mu \mathrm{M})\end{array}$ & $\begin{array}{l}0.78(0.6 \mu \mathrm{M}) \\
0.85(0.8 \mu \mathrm{M})\end{array}$ & $\begin{array}{l}41.87(0.6 \mu \mathrm{M}) \\
52.47(0.9 \mu \mathrm{M})\end{array}$ & $\begin{array}{l}3.10(0.6 \mu \mathrm{M}) \\
5.60(0.9 \mu \mathrm{M})\end{array}$ \\
\hline $4 c$ & $\begin{array}{r}6.21(0.7 \mu \mathrm{M}) \\
14.22(1.0 \mu \mathrm{M})\end{array}$ & $\begin{array}{l}1.67(0.7 \mu \mathrm{M}) \\
6.23(1.0 \mu \mathrm{M})\end{array}$ & $\begin{array}{l}15.30(0.9 \mu \mathrm{M}) \\
10.91(1.3 \mu \mathrm{M})\end{array}$ & $\begin{array}{l}3.02(0.9 \mu \mathrm{M}) \\
1.99(1.3 \mu \mathrm{M})\end{array}$ \\
\hline
\end{tabular}


using previously identified concentrations liable to determine expected antiproliferative effects, i.e. the $\mathrm{IC}_{50}$ and $\mathrm{IC}_{75}$ values against $\mathrm{A} 2780$ and A2780cis cell lines. Cisplatin was added to the cultured cells, demonstrating its evident and already reported pro-apoptotic effects on the A2780 cell line, when used at $1.0 \mu \mathrm{M}$ concentration (55.9\% of total apoptosis), while on the resistant A2780cis cells it was inactive at the same concentration. When the compounds were assayed on the A2780 cell line, at the used concentrations, the best pro-apoptotic activity was obtained with the complexes $\mathbf{1 b}, \mathbf{2 b}$ and $\mathbf{3 c}$ which were able to induce a very high percentage of apoptosis, exhibiting a better pro-apoptotic activity than cisplatin (Figure 4 and Table 3). Fully in agreement with the data shown in Table 2, derivatives $\mathbf{2 b}$ and $\mathbf{3 c}$ induced pro-apoptotic effects also on the resistant A2780cis cells. Compound $\mathbf{1 b}$ displayed low pro-apoptotic effects on A2780cis cells, whereas it was active on A2780 cells, suggesting a different mechanism of action with respect to compounds $\mathbf{2 b}$ and $\mathbf{3 c}$.

\section{3 | CONCLUSIONS}

We have synthesized twelve new palladacyclopentadienyl complexes bearing two NHCs or one NHC and one phosphine or isocyanide. In order to enhance the biological affinity of the complexes, three different compounds derived from modified natural xanthines were used as NHC ligands.

The cytotoxicity of the complexes towards the ovarian cancer cellular lines A2780 (cisplatin-sensitive) and A2780cis (cisplatin-resistant) was determined. Notably, with the exception of the bis-carbene derivative 1c, all the synthesized complexes show an antiproliferative activity comparable to that of cisplatin.

A correlation between the antiproliferative activity of the derivatives and their structure has been observed. In particular, the less hindered complexes of the type NHC-PTA or NHC-DIC show a higher efficiency with respect to the bis-NHC and the $\mathrm{NHC}-\mathrm{PPh}_{3}$ derivatives. Complexes 3 proved particularly promising since they are able to associate a significant antiproliferative activity, especially on A2780cis line, with the ability to induce apoptosis. Moreover, complex 3c, which is the most active species, is almost inactive against non-tumour cells (MRC-5 fibroblasts).

This observation might be important in view of possible application of the studied compounds in anticancer treatments, suggesting that preclinical investigations using different primary tumour cell isolates should be considered before proposing these compounds for clinical trials. In addition, it will be necessary in the future to investigate the activity using in vivo model systems, in order to clarify whether the described cytotoxicity against tumour cell lines involves negligible side effects on normal cells and networks.

Finally, the presence of PTA makes complexes $\mathbf{3}$ very soluble in water, a requisite that is very important for drug administration.

The natural development of this work will be to define the main cellular target and the mechanism of action of the most promising complexes.

\section{4 | EXPERIMENTAL}

\section{1 | Solvents and reagents}

The solvents $\mathrm{CH}_{2} \mathrm{Cl}_{2}$ and $\mathrm{CH}_{3} \mathrm{CN}$ were distilled over $\mathrm{CaH}_{2}$. Acetone was refluxed over $4 \AA$ molecular sieves and distilled. The precursor $\left[\mathrm{PdC}_{4}\left(\mathrm{COOCH}_{3}\right)_{4}\right]_{n}$ was synthesized according to published procedures. ${ }^{[18]}$ All other solvents and chemicals were commercial-grade products and used as purchased.

\subsection{IR and NMR spectroscopic measurements and elemental analysis}

The IR and ${ }^{1} \mathrm{H}$ NMR, ${ }^{13} \mathrm{C}$ NMR and ${ }^{31} \mathrm{P}$ NMR spectra were recorded with a PerkinElmer Spectrum One spectrophotometer and Bruker Avance 300 or Ascend 400 spectrometers, respectively. The elemental analysis of the synthesized complexes was carried out using an Elementar CHN CUBO Micro Vario analyser. ESI-MS analyses were carried out by the group of Prof. Sgarbossa (Padua University).

\section{3 | Crystal structure determinations}

The crystal data of compound $\mathbf{2 b}$ were collected at $100 \mathrm{~K}$ at the XRD1 beamline of the Elettra Synchrotron, Trieste (Italy). ${ }^{[30]}$ The datasets were integrated, scaled and corrected for Lorentz and polarization effects with the XDS package. ${ }^{[31]}$ The structure was solved by direct methods using the SHELXT program ${ }^{[32]}$ and refined using full-matrix least-squares with all non-hydrogen atoms anisotropically and hydrogens included on calculated positions, riding on their carrier atoms. Disordered water molecules were modelled in cavities, located on crystallographic inversion centres. The electron content per void area has been estimated to be $14 \mathrm{e}^{-}$( $c$ a $70 \AA^{3}$; PLATON $^{[33]}$ SQUEEZE routine), in agreement with refined water occupancies. Hydrogen atoms for water molecules were not included in the refined models since 
it was not possible to locate them unambiguously in electron-density peaks of Fourier difference maps (contributions of these missing hydrogen atoms are still included in the properties reported in Table S1, supporting information). All calculations were performed using SHELXL-2018/3. ${ }^{[34]}$ The Coot program was used for structure building. ${ }^{[35]}$ The crystal data are given in Table S1 (supporting information). Pictures were prepared using Ortep $3^{[21]}$ software.

Crystallographic data have been deposited at the Cambridge Crystallographic Data Centre and allocated the deposition number CCDC 1881566. These data can be obtained free of charge via https://www.ccdc.cam.ac. uk/structures.

\section{4 | Synthesis of purine-based imidazolium salts (a-c)}

These compounds were synthesized by chloride $-\mathrm{BF}_{4}$ metathesis of each tetrafluoroborate imidazolium salt obtained according to published procedures. ${ }^{[11]}$

\subsection{1 | Compound a}

To $356.2 \mathrm{mg}(1.203 \mathrm{mmol})$ of the tetrafluoroborate salt of tetramethylcaffeine, dissolved in $100 \mathrm{ml}$ of water, $503.9 \mathrm{mg}$ (1.203 mmol) of $\mathrm{AsPh}_{4} \mathrm{Cl}$ was added. The immediate formation of $\mathrm{AsPh}_{4} \mathrm{BF}_{4}$ as a white fluffy precipitate was observed. The reaction mixture was stirred for $c a$ 30 min and $\mathrm{AsPh}_{4} \mathrm{BF}_{4}$ was filtered off using a Millipore apparatus. The clear solution was dried under vacuum at low temperature $\left(<50^{\circ} \mathrm{C}\right)$ and the residue ground in $20 \mathrm{ml}$ of $\mathrm{CH}_{2} \mathrm{Cl}_{2}$, filtered off using a Gooch filter, washed with diethyl ether and dried under vacuum. An amount of $293.3 \mathrm{mg}$ (yield 99\%) of compound a was obtained as a white solid.

${ }^{1} \mathrm{H}$ NMR (400 MHz, $\left.\mathrm{CD}_{3} \mathrm{CN}, T=298 \mathrm{~K}, \delta, \mathrm{ppm}\right): 3.34$ (s, 3H, $\left.\mathrm{NCH}_{3}\right), 3.75\left(\mathrm{~s}, 3 \mathrm{H}, \mathrm{NCH}_{3}\right), 4.13\left(\mathrm{~s}, 3 \mathrm{H}, \mathrm{NCH}_{3}\right)$, 4.21 (s, 3H, $\mathrm{NCH}_{3}$ ), 10.03 (s, 1H, NCHN). ${ }^{13} \mathrm{C}\left\{{ }^{1} \mathrm{H}\right\} \mathrm{NMR}$ $\left(\mathrm{CD}_{3} \mathrm{CN}, T=298 \mathrm{~K}, \delta, \mathrm{ppm}\right): 28.6\left(\mathrm{CH}_{3}, \mathrm{NCH}_{3}\right), 31.8$ $\left(\mathrm{CH}_{3}, \mathrm{NCH}_{3}\right), 36.2\left(\mathrm{CH}_{3}, \mathrm{NCH}_{3}\right), 37.5\left(\mathrm{CH}_{3}, \mathrm{NCH}_{3}\right)$, $108.8\left(\mathrm{C}, \mathrm{C}^{5}\right), 140.1\left(\mathrm{C}, \mathrm{C}^{4}\right), 140.4(\mathrm{CH}, \mathrm{N}-\mathrm{CH}-\mathrm{N}), 151.1$ $(\mathrm{C}, \mathrm{C}=\mathrm{O}), 154.2(\mathrm{C}, \mathrm{C}=\mathrm{O})$. IR $(\mathrm{KBr}): v_{\mathrm{C}=\mathrm{O}}=1719$, $1675 \mathrm{~cm}^{-1}, v_{\mathrm{C}-\mathrm{O}}=1304,1264 \mathrm{~cm}^{-1}$.

Compounds $\mathbf{b}$ and $\mathbf{c}$ were prepared in a similar way from the appropriate reactants.

\subsection{2 | Compound $b$}

White solid; yield 98\%. ${ }^{1} \mathrm{H}$ NMR (400 $\mathrm{MHz}, \mathrm{CD}_{3} \mathrm{CN}$, $T=298 \mathrm{~K}, \delta, \mathrm{ppm}): 3.33\left(\mathrm{~s}, 3 \mathrm{H}, \mathrm{NCH}_{3}\right), 3.73(\mathrm{~s}, 3 \mathrm{H}$,
$\left.\mathrm{NCH}_{3}\right), \quad 4.10\left(\mathrm{~s}, 3 \mathrm{H}, \mathrm{NCH}_{3}\right), \quad 5.72\left(\mathrm{~s}, 2 \mathrm{H}, \mathrm{NCH}_{2}\right)$, 7.44-7.50 (m, 5H, Ph), $8.92(\mathrm{~s}, 1 \mathrm{H}, \mathrm{NCHN}) .{ }^{13} \mathrm{C}\left\{{ }^{1} \mathrm{H}\right\}$ NMR $\left(\mathrm{CD}_{3} \mathrm{CN}, T=298 \mathrm{~K}, \delta, \mathrm{ppm}\right): 28.2\left(\mathrm{CH}_{3}, \mathrm{NCH}_{3}\right)$, $31.2\left(\mathrm{CH}_{3}, \mathrm{NCH}_{3}\right), 37.3\left(\mathrm{CH}_{3}, \mathrm{NCH}_{3}\right), 52.0\left(\mathrm{CH}_{2}, \mathrm{NCH}_{2}\right)$, $107.8\left(\mathrm{C}, \mathrm{C}^{5}\right), 128.6-133.4(\mathrm{Ph}), 138.6(\mathrm{CH}, \mathrm{NCHN})$, $140.0\left(\mathrm{C}, \mathrm{C}^{4}\right), 150.4(\mathrm{C}, \mathrm{C}=\mathrm{O}), 153.4(\mathrm{C}, \mathrm{C}=\mathrm{O}) . \mathrm{IR}(\mathrm{KBr})$ : $v_{\mathrm{C}=\mathrm{O}}=1717,1671 \mathrm{~cm}^{-1}, v_{\mathrm{C}-\mathrm{O}}=1267 \mathrm{~cm}^{-1}$.

\subsection{3 | Compound $\mathrm{c}$}

White solid; yield 99\%. ${ }^{1} \mathrm{H}$ NMR (400 $\mathrm{MHz}, \mathrm{CD}_{3} \mathrm{CN}$, $T=298 \mathrm{~K}, \delta, \mathrm{ppm}): 3.73\left(\mathrm{~s}, 3 \mathrm{H}, \mathrm{NCH}_{3}\right), 4.09$ (s, 3H, $\left.\mathrm{NCH}_{3}\right), 4.10\left(\mathrm{~s}, 3 \mathrm{H}, \mathrm{NCH}_{3}\right), 5.16\left(\mathrm{~s}, 2 \mathrm{H}, \mathrm{NCH}_{2}\right)$, 7.33-7.39 (m, 5H, Ph), $8.82(\mathrm{~s}, 1 \mathrm{H}, \mathrm{NCHN}) .{ }^{13} \mathrm{C}\left\{{ }^{1} \mathrm{H}\right\}$ NMR $\left(\mathrm{CD}_{3} \mathrm{CN}, T=298 \mathrm{~K}, \delta, \mathrm{ppm}\right): 31.3\left(\mathrm{CH}_{3}, \mathrm{NCH}_{3}\right)$, $35.8\left(\mathrm{CH}_{3}, \mathrm{NCH}_{3}\right), 37.0\left(\mathrm{CH}_{3}, \mathrm{NCH}_{3}\right), 45.0\left(\mathrm{CH}_{2}, \mathrm{NCH}_{2}\right)$, $108.6\left(\mathrm{C}, \mathrm{C}^{5}\right), 127.7-136.5(\mathrm{Ph}), 139.0(\mathrm{CH}, \mathrm{NCHN})$, $139.8\left(\mathrm{C}, \mathrm{C}^{4}\right), 150.4(\mathrm{C}, \mathrm{C}=\mathrm{O}), 153.5(\mathrm{C}, \mathrm{C}=\mathrm{O})$. IR (KBr): $\nu_{\mathrm{C}=\mathrm{O}}=1722,1674 \mathrm{~cm}^{-1}$.

\section{5 | Synthesis of silver purine-based NHC complexes (Aga-c)}

\subsection{1 | Complex Aga}

To $142.5 \mathrm{mg}$ (0.5824 mmol) of compound a, dissolved in $35 \mathrm{ml}$ of anhydrous $\mathrm{CH}_{3} \mathrm{CN}$ in a two-necked flask under inert atmosphere (argon), $74.2 \mathrm{mg}(0.320 \mathrm{mmol})$ of $\mathrm{Ag}_{2} \mathrm{O}$ was added. The mixture was vigorously stirred in the dark for $4 \mathrm{~h}$ and a fluffy white solid, which was filtered off using a Gooch filter, was progressively formed. The white solid was dissolved in $200 \mathrm{ml}$ of $\mathrm{CH}_{2} \mathrm{Cl}_{2}$ and from the resulting mixture the $\mathrm{Ag}_{2} \mathrm{O}$ in excess removed by filtration in a Millipore apparatus. The clear solution was concentrated under vacuum and the complex Aga precipitated as white solid by addition of diethyl ether, filtered off using a Gooch filter and dried under vacuum. An amount of $121.4 \mathrm{mg}$ of the title complex was obtained (yield 60\%).

${ }^{1} \mathrm{H}$ NMR (400 MHz, $\mathrm{CD}_{2} \mathrm{Cl}_{2}, T=298 \mathrm{~K}, \delta, \mathrm{ppm}$ ): 3.41 (s, $\left.6 \mathrm{H}, 2 \mathrm{NCH}_{3}\right), 3.84\left(\mathrm{~s}, 6 \mathrm{H}, 2 \mathrm{NCH}_{3}\right), 4.17\left(\mathrm{~s}, 6 \mathrm{H}, 2 \mathrm{NCH}_{3}\right)$, $4.24\left(\mathrm{~s}, 6 \mathrm{H}, 2 \mathrm{NCH}_{3}\right) .{ }^{13} \mathrm{C}\left\{{ }^{1} \mathrm{H}\right\} \mathrm{NMR}$ (DMSO- $d_{6}, T=298 \mathrm{~K}$, $\delta$, ppm): $28.7\left(\mathrm{CH}_{3}, \mathrm{NCH}_{3}\right), 31.2\left(\mathrm{CH}_{3}, \mathrm{NCH}_{3}\right), 32.0\left(\mathrm{CH}_{3}\right.$, $\left.\mathrm{NCH}_{3}\right), 38.3\left(\mathrm{CH}_{3}, \mathrm{NCH}_{3}\right), 109.3\left(\mathrm{C}, \mathrm{C}^{5}\right), 140.9\left(\mathrm{C}, \mathrm{C}^{4}\right)$, $151.0(\mathrm{C}, \mathrm{C}=\mathrm{O}), 153.7(\mathrm{C}, \mathrm{C}=\mathrm{O}), 207.0$ (C, carbene). ESI-MS $\left(\mathrm{CH}_{3} \mathrm{CN}\right): m / z 525.04\left[\mathrm{Ag}(\mathrm{NHC})_{2}\right]^{+}$. IR $(\mathrm{KBr})$ : $\nu_{\mathrm{C}=\mathrm{O}}=1709,1669 \mathrm{~cm}^{-1}$.

Derivatives Agb and Agc were prepared in a similar way from the appropriate reactants. 


\subsection{2 | Complex Agb}

White solid; yield $67 \% .{ }^{1} \mathrm{H}$ NMR (400 $\mathrm{MHz}, \mathrm{CDCl}_{3}$, $T=298 \mathrm{~K}, \delta, \mathrm{ppm}): 3.31\left(\mathrm{~s}, 6 \mathrm{H}, 2 \mathrm{NCH}_{3}\right), 3.73(\mathrm{~s}, 6 \mathrm{H}$, $\left.2 \mathrm{NCH}_{3}\right), 4.16\left(\mathrm{~s}, 6 \mathrm{H}, 2 \mathrm{NCH}_{3}\right), 5.62\left(\mathrm{~s}, 4 \mathrm{H}, 2 \mathrm{NCH}_{2}\right)$, 7.20-7.41 (m, 10H, 2Ph). $\left.{ }^{13} \mathrm{C}^{1}{ }^{1} \mathrm{H}\right\} \quad \mathrm{NMR} \quad\left(\mathrm{CDCl}_{3}\right.$, $T=298 \mathrm{~K}, \delta, \mathrm{ppm}): 28.8\left(\mathrm{CH}_{3}, \mathrm{NCH}_{3}\right), 32.0\left(\mathrm{CH}_{3}\right.$, $\left.\mathrm{NCH}_{3}\right), 40.1\left(\mathrm{CH}_{3}, \mathrm{NCH}_{3}\right), 54.1\left(\mathrm{CH}_{2}, \mathrm{NCH}_{2}\right), 109.1(\mathrm{C}$, $\left.\mathrm{C}^{5}\right), 128.3-135.5(\mathrm{Ph}), 140.3\left(\mathrm{C}, \mathrm{C}^{4}\right), 150.6(\mathrm{C}, \mathrm{C}=\mathrm{O})$, $153.1(\mathrm{C}, \mathrm{C}=\mathrm{O}), 188.1$ (C, carbene). ESI-MS $\left(\mathrm{CH}_{3} \mathrm{CN}\right)$ : $m / z \quad 677.11 \quad\left[\mathrm{Ag}(\mathrm{NHC})_{2}\right]^{+}$. IR $(\mathrm{KBr}): v_{\mathrm{C}=\mathrm{O}}=1713$, $1673 \mathrm{~cm}^{-1}$.

\subsection{3 | Complex Agc}

White solid; yield $70 \% .{ }^{1} \mathrm{H}$ NMR $\left(400 \mathrm{MHz}, \mathrm{CDCl}_{3}\right.$, $T=298 \mathrm{~K}, \delta, \mathrm{ppm}): 3.83\left(\mathrm{~s}, 6 \mathrm{H}, 2 \mathrm{NCH}_{3}\right), 4.15(\mathrm{~s}, 6 \mathrm{H}$, $\left.2 \mathrm{NCH}_{3}\right), 4.19\left(\mathrm{~s}, 6 \mathrm{H}, 2 \mathrm{NCH}_{3}\right), 5.19\left(\mathrm{~s}, 4 \mathrm{H}, 2 \mathrm{NCH}_{2}\right)$, 7.29-7.50 (m, 10H, 2Ph). $\left.{ }^{13} \mathrm{C}^{1} \mathrm{H}\right\}$ NMR (DMSO- $d_{6}$, $T=298 \mathrm{~K}, \delta, \mathrm{ppm}): 31.2\left(\mathrm{CH}_{3}, \mathrm{NCH}_{3}\right), 32.1\left(\mathrm{CH}_{3}\right.$, $\left.\mathrm{NCH}_{3}\right), 38.3\left(\mathrm{CH}_{2}, \mathrm{NCH}_{2}\right), 109.3\left(\mathrm{C}, \mathrm{C}^{5}\right), 127.7-137.3$ $(\mathrm{Ph}), 141.3\left(\mathrm{C}, \mathrm{C}^{4}\right), 150.9(\mathrm{C}, \mathrm{C}=\mathrm{O}), 153.5(\mathrm{C}, \mathrm{C}=\mathrm{O})$, 206.9 (C, carbene). ESI-MS $\left(\mathrm{CH}_{3} \mathrm{CN}\right): \mathrm{m} / z \quad 677.08$ $\left[\mathrm{Ag}(\mathrm{NHC})_{2}\right]^{+}$. IR $(\mathrm{KBr}): v_{\mathrm{C}=\mathrm{O}}=1711,1674 \mathrm{~cm}^{-1}$.

\section{6 | Synthesis of bis-NHC palladacyclopentadienyl complexes (1)}

\subsection{1 | Complex 1a}

In a $50 \mathrm{ml}$ two necked flask, $18.2 \mathrm{mg}(0.0466 \mathrm{mmol})$ of $\left[\mathrm{PdC}_{4}\left(\mathrm{COOCH}_{3}\right)_{4}\right]_{n}$ was dissolved in $5 \mathrm{ml}$ of anhydrous $\mathrm{CH}_{2} \mathrm{Cl}_{2}$ under inert atmosphere (argon). An amount of $27.3 \mathrm{mg}(0.0388 \mathrm{mmol})$ of complex Aga, suspended in $25 \mathrm{ml}$ of anhydrous $\mathrm{CH}_{2} \mathrm{Cl}_{2}$, was added to the solution of $\left[\mathrm{PdC}_{4}\left(\mathrm{COOCH}_{3}\right)_{4}\right]_{n}$ and precipitation of $\mathrm{AgCl}$ was immediately observed. The mixture was reacted for $1 \mathrm{~h}$ at room temperature and then filtered using a Millipore apparatus. The clear yellow solution was concentrated under vacuum and the title complex precipitated by addition of diethyl ether. The yellow microcrystalline precipitate was filtered off using a Gooch filter, washed with diethyl ether and dried under vacuum. An amount of $21.3 \mathrm{mg}$ (70\% yield) of complex $\mathbf{1 a}$ was obtained.

${ }^{1} \mathrm{H}$ NMR (400 MHz, $\left.\mathrm{CD}_{2} \mathrm{Cl}_{2}, T=298 \mathrm{~K}, \delta, \mathrm{ppm}\right): 3.30$ $\left(\mathrm{s}, 12 \mathrm{H}, 4 \mathrm{OCH}_{3}\right), 3.36\left(\mathrm{~s}, 12 \mathrm{H}, 4 \mathrm{NCH}_{3}\right), 3.61(\mathrm{~s}, 12 \mathrm{H}, 4$ $\left.\mathrm{OCH}_{3}\right), 3.78\left(\mathrm{~s}, 6 \mathrm{H}, 2 \mathrm{NCH}_{3}\right), 3.79\left(\mathrm{~s}, 6 \mathrm{H}, 2 \mathrm{NCH}_{3}\right), 4.11$ $\left(\mathrm{s}, 6 \mathrm{H}, 2 \mathrm{NCH}_{3}\right), 4.15\left(\mathrm{~s}, 6 \mathrm{H}, 2 \mathrm{NCH}_{3}\right), 4.32(\mathrm{~s}, 6 \mathrm{H}$, $\left.2 \mathrm{NCH}_{3}\right), 4.34\left(\mathrm{~s}, 6 \mathrm{H}, 2 \mathrm{NCH}_{3}\right) \cdot{ }^{13} \mathrm{C}\left\{{ }^{1} \mathrm{H}\right\} \mathrm{NMR}\left(\mathrm{CD}_{2} \mathrm{Cl}_{2}\right.$, $T=298 \mathrm{~K}, \delta, \mathrm{ppm}): 28.3\left(\mathrm{CH}_{3}, \mathrm{NCH}_{3}\right), 31.8\left(\mathrm{CH}_{3}\right.$, $\left.\mathrm{NCH}_{3}\right), 37.2\left(\mathrm{CH}_{3}, \mathrm{NCH}_{3}\right), 37.4\left(\mathrm{CH}_{3}, \mathrm{NCH}_{3}\right), 39.2\left(\mathrm{CH}_{3}\right.$, $\left.\mathrm{NCH}_{3}\right), 39.3\left(\mathrm{CH}_{3}, \mathrm{NCH}_{3}\right), 50.6\left(\mathrm{CH}_{3}, \mathrm{OCH}_{3}\right), 51.0\left(\mathrm{CH}_{3}\right.$,
$\left.\mathrm{OCH}_{3}\right), \quad 109.8\left(\mathrm{C}, \quad \mathrm{C}^{5}\right), \quad 140.5 \quad\left(\mathrm{C}, \mathrm{C}^{4}\right), 144.6 \quad(\mathrm{C}$, $\left.\mathrm{C}-\mathrm{COOCH}_{3}\right), 150.6(\mathrm{C}, \mathrm{C}=\mathrm{O}), 153.0(\mathrm{C}, \mathrm{C}=\mathrm{O}), 164.8(\mathrm{C}$, $\left.\mathrm{COOCH}_{3}\right), 164.9\left(\mathrm{C}, \mathrm{COOCH}_{3}\right), 167.1\left(\mathrm{C}, \mathrm{C}-\mathrm{COOCH}_{3}\right)$, $167.2\left(\mathrm{C}, \mathrm{C}-\mathrm{COOCH}_{3}\right), 175.7\left(\mathrm{C}, \mathrm{COOCH}_{3}\right), 175.9(\mathrm{C}$, $\mathrm{COOCH}_{3}$ ), 188.1 (C, carbene), 188.4 (C, carbene). IR $(\mathrm{KBr}): v_{\mathrm{C}=\mathrm{O}}=1710,1672 \mathrm{~cm}^{-1}, v_{\mathrm{C}-\mathrm{O}}=1209 \mathrm{~cm}^{-1}$. Anal. Calcd for $\mathrm{C}_{30} \mathrm{H}_{36} \mathrm{~N}_{8} \mathrm{O}_{12} \mathrm{Pd}(\%)$ : C 44.65, H 4.50, N 13.88 . Found (\%): C 44.77, H 4.38, N 13.80.

Derivatives $\mathbf{1 b}$ and $\mathbf{1 c}$ were prepared in a similar way from the appropriate reactants.

\subsection{2 | Complex 1b}

Yellow microcrystals; yield $91 \% .{ }^{1} \mathrm{H}$ NMR (400 MHz, $\left.\mathrm{CD}_{2} \mathrm{Cl}_{2}, T=298 \mathrm{~K}, \delta, \mathrm{ppm}\right): 3.27$ (s, $\left.12 \mathrm{H}, 4 \mathrm{OCH}_{3}\right), 3.29$ (s, $\left.12 \mathrm{H}, 4 \mathrm{NCH}_{3}\right), 3.43\left(\mathrm{~s}, 6 \mathrm{H}, 2 \mathrm{NCH}_{3}\right), 3.61(\mathrm{~s}, 6 \mathrm{H}, 2$ $\left.\mathrm{OCH}_{3}\right), 3.63\left(\mathrm{~s}, 6 \mathrm{H}, 2 \mathrm{OCH}_{3}\right), 3.75\left(\mathrm{~s}, 6 \mathrm{H}, 2 \mathrm{NCH}_{3}\right), 3.79$ $\left(\mathrm{s}, 6 \mathrm{H}, 2 \mathrm{NCH}_{3}\right), 4.32\left(\mathrm{~s}, 6 \mathrm{H}, 2 \mathrm{NCH}_{3}\right), 4.98$ and $5.40(\mathrm{AB}$ system, $4 \mathrm{H}, J=15.5 \mathrm{~Hz}, 2 \mathrm{NCH}_{2}$ ), 5.77 and 5.85 (AB system, $\left.4 \mathrm{H}, J=16.3 \mathrm{~Hz}, 2 \mathrm{NCH}_{2}\right), 6.90-7.33(\mathrm{~m}, 20 \mathrm{H}, 4 \mathrm{Ph})$. ${ }^{13} \mathrm{C}\left\{{ }^{1} \mathrm{H}\right\}$ NMR $\left(\mathrm{CD}_{2} \mathrm{Cl}_{2}, T=298 \mathrm{~K}, \delta, \mathrm{ppm}\right): 28.3\left(\mathrm{CH}_{3}\right.$, $\left.\mathrm{NCH}_{3}\right), 31.5\left(\mathrm{CH}_{3}, \mathrm{NCH}_{3}\right), 31.9\left(\mathrm{CH}_{3}, \mathrm{NCH}_{3}\right), 38.4\left(\mathrm{CH}_{3}\right.$, $\left.\mathrm{NCH}_{3}\right), 39.4\left(\mathrm{CH}_{3}, \mathrm{NCH}_{3}\right), 50.6\left(\mathrm{CH}_{3}, \mathrm{OCH}_{3}\right), 51.0\left(\mathrm{CH}_{3}\right.$, $\left.\mathrm{OCH}_{3}\right), 52.7\left(\mathrm{CH}_{2}, \mathrm{NCH}_{2}\right), 109.0\left(\mathrm{C}, \mathrm{C}^{5}\right), 109.5\left(\mathrm{C}, \mathrm{C}^{5}\right)$, 125.1-136.7 (Ph), $140.7\left(\mathrm{C}, \mathrm{C}^{4}\right), 140.8\left(\mathrm{C}, \mathrm{C}^{4}\right), 145.1(\mathrm{C}$, $\left.\mathrm{C}-\mathrm{COOCH}_{3}\right), 145.2\left(\mathrm{C}, \mathrm{C}-\mathrm{COOCH}_{3}\right), 150.4(\mathrm{C}, \mathrm{C}=\mathrm{O})$, $150.5(\mathrm{C}, \mathrm{C}=\mathrm{O}), 152.3(\mathrm{C}, \mathrm{C}=\mathrm{O}), 164.8\left(\mathrm{C}, \mathrm{COOCH}_{3}\right)$, $165.1\left(\mathrm{C}, \mathrm{COOCH}_{3}\right), 166.7\left(\mathrm{C}, \mathrm{C}-\mathrm{COOCH}_{3}\right), 167.1$ (C, $\left.\mathrm{C}-\mathrm{COOCH}_{3}\right), 175.4\left(\mathrm{C}, \mathrm{COOCH}_{3}\right), 188.6$ (C, carbene), 189.1 (C, carbene). IR ( $\mathrm{KBr}): v_{\mathrm{C}=\mathrm{O}}=1710,1668 \mathrm{~cm}^{-1}$, $v_{\mathrm{C}-\mathrm{O}}=1206 \mathrm{~cm}^{-1}$. Anal. Calcd for $\mathrm{C}_{42} \mathrm{H}_{44} \mathrm{~N}_{8} \mathrm{O}_{12} \mathrm{Pd}(\%)$ : C 52.59, H 4.62, N 11.68. Found (\%): C 52.74, H 4.79, N 11.57 .

\subsection{3 | Complex 1c}

Yellow microcrystals; yield $80 \% .{ }^{1} \mathrm{H}$ NMR (400 MHz, $\left.\mathrm{CDCl}_{3}, T=298 \mathrm{~K}, \delta, \mathrm{ppm}\right): 3.28\left(\mathrm{~s}, 6 \mathrm{H}, 2 \mathrm{OCH}_{3}\right), 3.31$ (s, $\left.6 \mathrm{H}, 2 \mathrm{OCH}_{3}\right), 3.62\left(\mathrm{~s}, 6 \mathrm{H}, 2 \mathrm{OCH}_{3}\right), 3.64\left(\mathrm{~s}, 6 \mathrm{H}, 2 \mathrm{OCH}_{3}\right)$, $3.74\left(\mathrm{~s}, 6 \mathrm{H}, 2 \mathrm{NCH}_{3}\right), 3.78\left(\mathrm{~s}, 6 \mathrm{H}, 2 \mathrm{NCH}_{3}\right), 4.09(\mathrm{~s}, 6 \mathrm{H}$, $\left.2 \mathrm{NCH}_{3}\right), 4.13\left(\mathrm{~s}, 6 \mathrm{H}, 2 \mathrm{NCH}_{3}\right), 4.35\left(\mathrm{~s}, 6 \mathrm{H}, 2 \mathrm{NCH}_{3}\right), 4.36$ $\left(\mathrm{s}, 6 \mathrm{H}, 2 \mathrm{NCH}_{3}\right), 5.14\left(\mathrm{~m}, 8 \mathrm{H}, 4 \mathrm{NCH}_{2}\right), 7.27-7.40(\mathrm{~m}$, 20H, 4Ph). ${ }^{13} \mathrm{C}\left\{{ }^{1} \mathrm{H}\right\}$ NMR $\left(\mathrm{CDCl}_{3}, T=298 \mathrm{~K}, \delta, \mathrm{ppm}\right)$ : $31.9\left(\mathrm{CH}_{3}, \mathrm{NCH}_{3}\right), 32.0\left(\mathrm{CH}_{3}, \mathrm{NCH}_{3}\right), 37.4\left(\mathrm{CH}_{3}, \mathrm{NCH}_{3}\right)$, $37.6\left(\mathrm{CH}_{3}, \mathrm{NCH}_{3}\right), 39.4\left(\mathrm{CH}_{3}, \mathrm{NCH}_{3}\right), 39.6\left(\mathrm{CH}_{3}, \mathrm{NCH}_{3}\right)$, $45.1\left(\mathrm{CH}_{2}, \mathrm{NCH}_{2}\right), 50.8\left(\mathrm{CH}_{3}, \mathrm{OCH}_{3}\right), 51.3\left(\mathrm{CH}_{3}, \mathrm{OCH}_{3}\right)$, $109.9\left(\mathrm{C}, \mathrm{C}^{5}\right), 127.9-136.3(\mathrm{Ph}), 140.7\left(\mathrm{C}, \mathrm{C}^{4}\right), 140.8(\mathrm{C}$, $\left.\mathrm{C}^{4}\right), 145.0\left(\mathrm{C}, \mathrm{C}-\mathrm{COOCH}_{3}\right), 145.3\left(\mathrm{C}, \mathrm{C}-\mathrm{COOCH}_{3}\right)$, $150.4(\mathrm{C}, \mathrm{C}=\mathrm{O}), 152.9(\mathrm{C}, \mathrm{C}=\mathrm{O}), 165.0\left(\mathrm{C}, \mathrm{COOCH}_{3}\right)$, $165.2\left(\mathrm{C}, \mathrm{COOCH}_{3}\right), 166.6\left(\mathrm{C}, \mathrm{C}-\mathrm{COOCH}_{3}\right), 166.9(\mathrm{C}$, $\left.\mathrm{C}-\mathrm{COOCH}_{3}\right), 176.1\left(\mathrm{C}, \mathrm{COOCH}_{3}\right), 176.2\left(\mathrm{C}, \mathrm{COOCH}_{3}\right)$, 188.3 (C, carbene), 189.1 (C, carbene). IR (KBr): 
$v_{\mathrm{C}=\mathrm{O}}=1709,1671 \mathrm{~cm}^{-1}, v_{\mathrm{C}-\mathrm{O}}=1208 \mathrm{~cm}^{-1}$. Anal. Calcd for $\mathrm{C}_{42} \mathrm{H}_{44} \mathrm{~N}_{8} \mathrm{O}_{12} \mathrm{Pd}(\%)$ : C 52.59, $\mathrm{H}$ 4.62, N 11.68. Found (\%): C 52.74, H 4.56, N 11.67.

\subsection{Synthesis of mixed NHC-PPh 3 and NHC-PTA palladacyclopentadienyl complexes (2 and 3)}

\subsection{1 | Complex 2a}

In a $50 \mathrm{ml}$ two-necked flask, $27.9 \mathrm{mg}(0.0713 \mathrm{mmol})$ of $\left[\mathrm{PdC}_{4}\left(\mathrm{COOCH}_{3}\right)_{4}\right]_{n}$ was dissolved in $5 \mathrm{ml}$ of anhydrous $\mathrm{CH}_{2} \mathrm{Cl}_{2}$ under inert atmosphere (argon). An amount of $21.8 \mathrm{mg}(0.0310 \mathrm{mmol})$ of complex Aga and $17.1 \mathrm{mg}$ ( $0.0651 \mathrm{mmol})$ of $\mathrm{PPh}_{3}$, suspended in $30 \mathrm{ml}$ of anhydrous $\mathrm{CH}_{2} \mathrm{Cl}_{2}$, were added to the solution of $\left[\mathrm{PdC}_{4}\left(\mathrm{COOCH}_{3}\right)_{4}\right]_{n}$ and precipitation of $\mathrm{AgCl}$ was immediately observed. The mixture was reacted for $1 \mathrm{~h}$ at room temperature and then filtered using a Millipore apparatus. The clear yellow solution was concentrated under vacuum and the title complex precipitated by addition of diethyl ether. The yellow microcrystalline precipitate was filtered off using a Gooch filter, washed with diethyl ether and dried in a desiccator. An amount of $509 \mathrm{mg}$ (83\% yield) of complex 2a was obtained.

${ }^{1} \mathrm{H} \mathrm{NMR}\left(400 \mathrm{MHz}, \mathrm{CDCl}_{3}, T=298 \mathrm{~K}, \delta, \mathrm{ppm}\right): 2.53$ (s, $\left.3 \mathrm{H}, \mathrm{OCH}_{3}\right), 3.25\left(\mathrm{~s}, 3 \mathrm{H}, \mathrm{OCH}_{3}\right), 3.36\left(\mathrm{~s}, 3 \mathrm{H}, \mathrm{NCH}_{3}\right), 3.48$ $\left(\mathrm{s}, 3 \mathrm{H}, \mathrm{NCH}_{3}\right), 3.63\left(\mathrm{~s}, 3 \mathrm{H}, \mathrm{OCH}_{3}\right), 3.65\left(\mathrm{~s}, 3 \mathrm{H}, \mathrm{OCH}_{3}\right)$, $3.76\left(\mathrm{~s}, 3 \mathrm{H}, \mathrm{NCH}_{3}\right), 3.82\left(\mathrm{~s}, 3 \mathrm{H}, \mathrm{NCH}_{3}\right), 7.32-7.51(\mathrm{~m}$, 15H, 3Ph). ${ }^{13} \mathrm{C}\left\{{ }^{1} \mathrm{H}\right\} \mathrm{NMR}\left(\mathrm{CDCl}_{3}, T=298 \mathrm{~K}, \delta, \mathrm{ppm}\right)$ : $28.6\left(\mathrm{CH}_{3}, \mathrm{NCH}_{3}\right), 31.5\left(\mathrm{CH}_{3}, \mathrm{NCH}_{3}\right), 36.6\left(\mathrm{CH}_{3}, \mathrm{NCH}_{3}\right)$, $38.2\left(\mathrm{CH}_{3}, \mathrm{NCH}_{3}\right), 50.0\left(\mathrm{CH}_{3}, \mathrm{OCH}_{3}\right), 50.8\left(\mathrm{CH}_{3}, \mathrm{OCH}_{3}\right)$, $51.2\left(\mathrm{CH}_{3}, \mathrm{OCH}_{3}\right), 51.3\left(\mathrm{CH}_{3}, \mathrm{OCH}_{3}\right), 109.7\left(\mathrm{C}, \mathrm{C}^{5}\right)$, 128.3-134.1 (Ph), $140.2\left(\mathrm{C}, \mathrm{C}^{4}\right), 145.9\left(\mathrm{~d}, \mathrm{C}, J_{\mathrm{C}-\mathrm{P}}=5.4 \mathrm{~Hz}\right.$, $\left.C-\mathrm{COOCH}_{3}\right), 148.8\left(\mathrm{~d}, \mathrm{C}, J_{\mathrm{C}-\mathrm{P}}=7.0 \mathrm{~Hz}, \mathrm{C}-\mathrm{COOCH}_{3}\right)$, $150.2(\mathrm{C}, \mathrm{C}=\mathrm{O}), \quad 152.7(\mathrm{C}, \mathrm{C}=\mathrm{O}), \quad 164.0-166.4 \quad(\mathrm{C}$, $\left.\mathrm{COOCH}_{3}\right), \quad 168.1 \quad\left(\mathrm{C}, \quad \mathrm{C}-\mathrm{COOCH}_{3}\right), \quad 169.6 \quad(\mathrm{C}$, $\left.C-\mathrm{COOCH}_{3}\right), 174.9\left(\mathrm{~d}, \mathrm{C}, J_{\mathrm{C}-\mathrm{P}}=4.9 \mathrm{~Hz}, \mathrm{COOCH}_{3}\right)$, $175.6\left(\mathrm{~d}, \mathrm{C}, J_{\mathrm{C}-\mathrm{P}}=5.3 \mathrm{~Hz}, C \mathrm{COCH}_{3}\right), 189.1(\mathrm{~d}, \mathrm{C}$, $J_{\mathrm{C}-\mathrm{P}}=15.8 \mathrm{~Hz}$, carbene). ${ }^{31} \mathrm{P}\left\{{ }^{1} \mathrm{H}\right\} \quad \mathrm{NMR}\left(\mathrm{CDCl}_{3}\right.$, $T=298 \mathrm{~K}, \delta, \mathrm{ppm}): 26.1 . \mathrm{IR}(\mathrm{KBr}): \nu_{\mathrm{C}=\mathrm{O}}=1730$, $1692 \mathrm{~cm}^{-1}, \nu_{\mathrm{C}-\mathrm{O}}=1212 \mathrm{~cm}^{-1}$. Anal. Calcd for $\mathrm{C}_{39} \mathrm{H}_{39} \mathrm{~N}_{4} \mathrm{O}_{10}$ PPd (\%): C 54.39, H 4.56, N 6.51. Found (\%): C 54.49, H 4.51, N 6.62.

Derivatives $\mathbf{2 b}, \mathbf{2 c}, \mathbf{3 a}, \mathbf{3 b}$ and $\mathbf{3 c}$ were prepared in a similar way from the appropriate reactants.

\subsection{2 | Complex 2b}

Yellow microcrystals; yield 86\%. ${ }^{1} \mathrm{H}$ NMR (400 MHz, $\left.\mathrm{CDCl}_{3}, T=298 \mathrm{~K}, \delta, \mathrm{ppm}\right): 2.56\left(\mathrm{~s}, 3 \mathrm{H}, \mathrm{OCH}_{3}\right), 3.04(\mathrm{~s}$, $\left.3 \mathrm{H}, \mathrm{OCH}_{3}\right), 3.38\left(\mathrm{~s}, 3 \mathrm{H}, \mathrm{NCH}_{3}\right), 3.46\left(\mathrm{~s}, 3 \mathrm{H}, \mathrm{NCH}_{3}\right), 3.63$ (s, $\left.3 \mathrm{H}, \mathrm{OCH}_{3}\right), 3.64\left(\mathrm{~s}, 3 \mathrm{H}, \mathrm{OCH}_{3}\right), 3.85\left(\mathrm{~s}, 3 \mathrm{H}, \mathrm{NCH}_{3}\right)$, 5.40 and $5.50\left(\mathrm{AB}\right.$ system, $\left.2 \mathrm{H}, J=14.2 \mathrm{~Hz}, \mathrm{NCH}_{2}\right)$, 7.12-7.52 (m, 20H, 4Ph). ${ }^{13} \mathrm{C}\left\{{ }^{1} \mathrm{H}\right\} \quad \mathrm{NMR} \quad\left(\mathrm{CDCl}_{3}\right.$, $T=298 \mathrm{~K}, \delta, \mathrm{ppm}): 28.7\left(\mathrm{CH}_{3}, \mathrm{NCH}_{3}\right), 31.8\left(\mathrm{CH}_{3}\right.$, $\left.\mathrm{NCH}_{3}\right), 39.0\left(\mathrm{CH}_{3}, \mathrm{NCH}_{3}\right), 50.0\left(\mathrm{CH}_{3}, \mathrm{OCH}_{3}\right), 50.9\left(\mathrm{CH}_{3}\right.$, $\left.\mathrm{OCH}_{3}\right), 51.2\left(\mathrm{CH}_{3}, \mathrm{OCH}_{3}\right), 51.3\left(\mathrm{CH}_{3}, \mathrm{OCH}_{3}\right), 53.6\left(\mathrm{CH}_{2}\right.$, $\left.\mathrm{NCH}_{2}\right), 109.5\left(\mathrm{C}, \mathrm{C}^{5}\right), 128.2-134.7(\mathrm{Ph}), 140.9\left(\mathrm{C}, \mathrm{C}^{4}\right)$, $148.8\left(\mathrm{~d}, \mathrm{C}, J_{\mathrm{C}-\mathrm{P}}=5.6 \mathrm{~Hz}, C-\mathrm{COOCH}_{3}\right), 149.0\left(\mathrm{~d}, \mathrm{C}, J_{\mathrm{C}-}\right.$ $\left.\mathrm{P}=7.3 \mathrm{~Hz}, \mathrm{C}-\mathrm{COOCH}_{3}\right), 150.3(\mathrm{C}, \mathrm{C}=\mathrm{O}), 152.7(\mathrm{C}$, $\mathrm{C}=\mathrm{O}), 164.9-165.1\left(\mathrm{C}, \mathrm{COOCH}_{3}\right), 166.0\left(\mathrm{C}, \mathrm{C}-\mathrm{COOCH}_{3}\right)$, $166.4\left(\mathrm{C}, C-\mathrm{COOCH}_{3}\right), 174.5\left(\mathrm{~d}, \mathrm{C}, J_{\mathrm{C}-\mathrm{P}}=5.2 \mathrm{~Hz}\right.$, $\left.\mathrm{COOCH}_{3}\right), 174.9\left(\mathrm{~d}, \mathrm{C}, J_{\mathrm{C}-\mathrm{P}}=6.4 \mathrm{~Hz}, \mathrm{COOCH}_{3}\right), 189.4$ (d, C, $J_{\mathrm{C}-\mathrm{P}}=15.5 \mathrm{~Hz}$, carbene). ${ }^{31} \mathrm{P}\left\{{ }^{1} \mathrm{H}\right\} \mathrm{NMR}\left(\mathrm{CDCl}_{3}\right.$, $T=298 \mathrm{~K}, \delta, \mathrm{ppm}): 25.1$. IR $(\mathrm{KBr}): \nu_{\mathrm{C}=\mathrm{O}}=1710$, $1670 \mathrm{~cm}^{-1}, \nu_{\mathrm{C}-\mathrm{O}}=1208 \mathrm{~cm}^{-1}$. Anal. Calcd for $\mathrm{C}_{45} \mathrm{H}_{43} \mathrm{~N}_{4} \mathrm{O}_{10}$ PPd (\%): C 57.67, H 4.62, N 5.98. Found (\%): C 57.81, H 4.73, N 5.87.

\subsection{3 | Complex 2c}

Yellow microcrystals; yield $85 \% .{ }^{1} \mathrm{H}$ NMR (400 MHz, $\left.\mathrm{CDCl}_{3}, T=298 \mathrm{~K}, \delta, \mathrm{ppm}\right): 2.53\left(\mathrm{~s}, 3 \mathrm{H}, \mathrm{OCH}_{3}\right), 3.24(\mathrm{~s}$, $\left.3 \mathrm{H}, \mathrm{OCH}_{3}\right), 3.48\left(\mathrm{~s}, 3 \mathrm{H}, \mathrm{NCH}_{3}\right), 3.63\left(\mathrm{~s}, 3 \mathrm{H}, \mathrm{OCH}_{3}\right), 3.65$ $\left(\mathrm{s}, 3 \mathrm{H}, \mathrm{OCH}_{3}\right), 3.80\left(\mathrm{~s}, 6 \mathrm{H}, 2 \mathrm{NCH}_{3}\right), 5.08$ and $5.13(\mathrm{AB}$ system, $\left.2 \mathrm{H}, J=14.5 \mathrm{~Hz}, \mathrm{NCH}_{2}\right), 7.24-7.50(\mathrm{~m}, 20 \mathrm{H}$, 4Ph). ${ }^{13} \mathrm{C}\left\{{ }^{1} \mathrm{H}\right\} \operatorname{NMR}\left(\mathrm{CDCl}_{3}, T=298 \mathrm{~K}, \delta, \mathrm{ppm}\right): 31.6$ $\left(\mathrm{CH}_{3}, \mathrm{NCH}_{3}\right), 36.6\left(\mathrm{CH}_{3}, \mathrm{NCH}_{3}\right), 38.3\left(\mathrm{CH}_{3}, \mathrm{NCH}_{3}\right), 45.0$ $\left(\mathrm{CH}_{2}, \mathrm{NCH}_{2}\right), 49.9\left(\mathrm{CH}_{3}, \mathrm{OCH}_{3}\right), 50.8\left(\mathrm{CH}_{3}, \mathrm{OCH}_{3}\right), 51.2$ $\left(\mathrm{CH}_{3}, \mathrm{OCH}_{3}\right), \quad 51.3 \quad\left(\mathrm{CH}_{3}, \mathrm{OCH}_{3}\right), 109.9\left(\mathrm{C}, \mathrm{C}^{5}\right)$, 128.0-136.5 (Ph), $140.1\left(\mathrm{C}, \mathrm{C}^{4}\right), 145.9\left(\mathrm{~d}, \mathrm{C}, J_{\mathrm{C}-\mathrm{P}}=5.5 \mathrm{~Hz}\right.$, $\left.C-\mathrm{COOCH}_{3}\right), 148.8\left(\mathrm{~d}, \mathrm{C}, J_{\mathrm{C}-\mathrm{P}}=7.1 \mathrm{~Hz}, \mathrm{C}-\mathrm{COOCH}_{3}\right)$, $150.1(\mathrm{C}, \mathrm{C}=\mathrm{O}), 152.5(\mathrm{C}, \mathrm{C}=\mathrm{O}), 164.1-166.3 \quad(\mathrm{C}$, $\left.\mathrm{COOCH}_{3}\right), \quad 168.1 \quad\left(\mathrm{C}, \quad \mathrm{C}-\mathrm{COOCH}_{3}\right), \quad 169.2 \quad(\mathrm{C}$, $\left.C-\mathrm{COOCH}_{3}\right), 174.3\left(\mathrm{~d}, \mathrm{C}, J_{\mathrm{C}-\mathrm{P}}=5.5 \mathrm{~Hz}, \mathrm{COOCH}_{3}\right.$ ), $175.6\left(\mathrm{~d}, \mathrm{C}, J_{\mathrm{C}-\mathrm{P}}=5.5 \mathrm{~Hz}, \mathrm{COOCH}_{3}\right), 189.4(\mathrm{~d}, \mathrm{C}$, $J_{\mathrm{C}-\mathrm{P}}=16.0 \mathrm{~Hz}$, carbene $) .{ }^{31} \mathrm{P}\left\{{ }^{1} \mathrm{H}\right\} \quad \mathrm{NMR}\left(\mathrm{CDCl}_{3}\right.$, $T=298 \mathrm{~K}, \delta, \mathrm{ppm}): 26.2$. IR $(\mathrm{KBr}): \nu_{\mathrm{C}=\mathrm{O}}=1699$, $1674 \mathrm{~cm}^{-1}, \quad \nu_{\mathrm{C}-\mathrm{O}}=1205 \mathrm{~cm}^{-1}$. Anal. Calcd for $\mathrm{C}_{45} \mathrm{H}_{43} \mathrm{~N}_{4} \mathrm{O}_{10}$ PPd (\%): C 57.67, H 4.62, N 5.98. Found (\%): C 57.78, H 4.85, N 6.02 .

\subsection{4 | Complex 3a}

Brown microcrystals; yield 91\%. ${ }^{1} \mathrm{H}$ NMR (400 MHz, $\left.\mathrm{CDCl}_{3}, T=298 \mathrm{~K}, \delta, \mathrm{ppm}\right): 3.28\left(\mathrm{~s}, 3 \mathrm{H}, \mathrm{OCH}_{3}\right), 3.42$ (s, $\left.3 \mathrm{H}, \mathrm{NCH}_{3}\right), 3.61\left(\mathrm{~s}, 3 \mathrm{H}, \mathrm{OCH}_{3}\right), 3.68\left(\mathrm{~s}, 3 \mathrm{H}, \mathrm{OCH}_{3}\right), 3.80$ $\left(\mathrm{s}, 3 \mathrm{H}, \mathrm{OCH}_{3}\right), 3.84\left(\mathrm{~s}, 3 \mathrm{H}, \mathrm{NCH}_{3}\right), 4.00(\mathrm{~d}, 6 \mathrm{H}$, $\left.J=2.1 \mathrm{~Hz}, 3 \mathrm{NCH}_{2} \mathrm{P}\right), 4.04\left(\mathrm{~s}, 3 \mathrm{H}, \mathrm{NCH}_{3}\right), 4.20(\mathrm{~s}, 3 \mathrm{H}$, $\left.\mathrm{NCH}_{3}\right), 4.49\left(\mathrm{~s}, 6 \mathrm{H}, 3 \mathrm{NCH}_{2} \mathrm{~N}\right) .{ }^{13} \mathrm{C}\left\{{ }^{1} \mathrm{H}\right\} \mathrm{NMR}\left(\mathrm{CDCl}_{3}\right.$, $T=298 \mathrm{~K}, \delta, \mathrm{ppm}): 28.7\left(\mathrm{CH}_{3}, \mathrm{NCH}_{3}\right), 32.0\left(\mathrm{CH}_{3}\right.$, $\left.\mathrm{NCH}_{3}\right), 37.0\left(\mathrm{CH}_{3}, \mathrm{NCH}_{3}\right), 38.9\left(\mathrm{CH}_{3}, \mathrm{NCH}_{3}\right), 50.9\left(\mathrm{CH}_{3}\right.$, $\left.\mathrm{OCH}_{3}\right), 51.1\left(\mathrm{~d}, \mathrm{CH}_{2}, J_{\mathrm{C}-\mathrm{P}}=10.2 \mathrm{~Hz}, \mathrm{NCH}_{2} \mathrm{P}\right), 51.2$ 
$\left(\mathrm{CH}_{3}, \mathrm{OCH}_{3}\right), 51.4\left(\mathrm{CH}_{3}, \mathrm{OCH}_{3}\right), 51.6\left(\mathrm{CH}_{3}, \mathrm{OCH}_{3}\right), 73.1$ $\left(\mathrm{d}, \mathrm{CH}_{2}, J_{\mathrm{C}-\mathrm{P}}=6.4 \mathrm{~Hz}, \mathrm{NCH}_{2} \mathrm{~N}\right), 110.1\left(\mathrm{C}, \mathrm{C}^{5}\right), 140.6(\mathrm{C}$, $\left.\mathrm{C}^{4}\right), 164.3-165.0\left(\mathrm{C}, \mathrm{COOCH}_{3}\right), 165.4\left(\mathrm{C}, \mathrm{C}-\mathrm{COOCH}_{3}\right)$, $168.7\left(\mathrm{C}, C-\mathrm{COOCH}_{3}\right), 175.1\left(\mathrm{~d}, \mathrm{C}, J_{\mathrm{C}-\mathrm{P}}=5.7 \mathrm{~Hz}\right.$, $\left.\mathrm{COOCH}_{3}\right), 177.3\left(\mathrm{~d}, \mathrm{C}, J_{\mathrm{C}-\mathrm{P}}=5.8 \mathrm{~Hz}, \mathrm{COOCH}_{3}\right), 186.9$ (d, C, $J_{\mathrm{C}-\mathrm{P}}=18.4 \mathrm{~Hz}$, carbene). ${ }^{31} \mathrm{P}\left\{{ }^{1} \mathrm{H}\right\}$ NMR $\left(\mathrm{CDCl}_{3}\right.$, $T=298 \mathrm{~K}, \delta, \mathrm{ppm}):-64.8 . \mathrm{IR}(\mathrm{KBr}): \nu_{\mathrm{C}=\mathrm{O}}=1711$, $1672 \mathrm{~cm}^{-1}, \nu_{\mathrm{C}-\mathrm{O}}=1206 \mathrm{~cm}^{-1}$. Anal. Calcd for $\mathrm{C}_{27} \mathrm{H}_{36} \mathrm{~N}_{7} \mathrm{O}_{10} \mathrm{PPd}(\%): \mathrm{C} 42.89, \mathrm{H} 4.80, \mathrm{~N}$ 12.97. Found (\%): C 42.72, H 4.93, N 12.82.

\subsection{5 | Complex 3b}

Brown microcrystals; yield 90\%. ${ }^{1} \mathrm{H}$ NMR (400 MHz, $\left.\mathrm{CDCl}_{3}, T=298 \mathrm{~K}, \delta, \mathrm{ppm}\right): 3.23\left(\mathrm{~s}, 3 \mathrm{H}, \mathrm{OCH}_{3}\right), 3.40$ (s, $\left.9 \mathrm{H}, 3 \mathrm{NCH}_{2} \mathrm{P}+\mathrm{NCH}_{3}\right), 3.53\left(\mathrm{~s}, 3 \mathrm{H}, \mathrm{OCH}_{3}\right), 3.61(\mathrm{~s}, 3 \mathrm{H}$, $\left.\mathrm{OCH}_{3}\right), 3.71\left(\mathrm{~s}, 3 \mathrm{H}, \mathrm{OCH}_{3}\right), 3.78\left(\mathrm{~s}, 3 \mathrm{H}, \mathrm{NCH}_{3}\right), 4.14$ (s, $3 \mathrm{H}, \mathrm{NCH}_{3}$ ), 4.06 and 4.20 (AB system, $6 \mathrm{H}, J=14.8 \mathrm{~Hz}$, $3 \mathrm{NCH}_{2} \mathrm{~N}$ ), 5.19 and $6.02(\mathrm{AB}$ system, $2 \mathrm{H}, J=13.4 \mathrm{~Hz}$, $\left.\mathrm{NCH}_{2}\right), 7.34-7.44(\mathrm{~m}, 5 \mathrm{H}, \mathrm{Ph}) .{ }^{13} \mathrm{C}\left\{{ }^{1} \mathrm{H}\right\} \mathrm{NMR}\left(\mathrm{CDCl}_{3}\right.$, $T=298 \mathrm{~K}, \delta, \mathrm{ppm}): 28.8\left(\mathrm{CH}_{3}, \mathrm{NCH}_{3}\right), 32.2\left(\mathrm{CH}_{3}\right.$, $\left.\mathrm{NCH}_{3}\right), 39.3\left(\mathrm{CH}_{3}, \mathrm{NCH}_{3}\right), 50.1\left(\mathrm{~d}, \mathrm{CH}_{2}, J_{\mathrm{C}-\mathrm{P}}=10.0 \mathrm{~Hz}\right.$, $\left.\mathrm{NCH}_{2} \mathrm{P}\right), 51.0\left(\mathrm{CH}_{3}, \mathrm{OCH}_{3}\right), 51.3\left(\mathrm{CH}_{3}, \mathrm{OCH}_{3}\right), 51.4$ $\left(\mathrm{CH}_{3}, \mathrm{OCH}_{3}\right), 51.6\left(\mathrm{CH}_{3}, \mathrm{OCH}_{3}\right), 52.8\left(\mathrm{CH}_{2}, \mathrm{NCH}_{2}\right), 72.7$ $\left(\mathrm{d}, \mathrm{CH}_{2}, J_{\mathrm{C}-\mathrm{P}}=6.5 \mathrm{~Hz}, \mathrm{NCH}_{2} \mathrm{~N}\right), 110.1\left(\mathrm{C}, \mathrm{C}^{5}\right)$, $128.6-136.5(\mathrm{Ph}), \quad 140.6 \quad\left(\mathrm{C}, \mathrm{C}^{4}\right), \quad 164.7-165.2 \quad(\mathrm{C}$, $\left.\mathrm{COOCH}_{3}\right), \quad 166.6 \quad\left(\mathrm{C}, \quad \mathrm{C}-\mathrm{COOCH}_{3}\right), \quad 167.7 \quad(\mathrm{C}$, $\left.C-\mathrm{COOCH}_{3}\right), 175.1\left(\mathrm{~d}, \mathrm{C}, J_{\mathrm{C}-\mathrm{P}}=5.5 \mathrm{~Hz}, \mathrm{COOCH}_{3}\right)$, $177.3\left(\mathrm{~d}, \mathrm{C}, J_{\mathrm{C}-\mathrm{P}}=5.9 \mathrm{~Hz}, \mathrm{COOCH}_{3}\right), 188.0(\mathrm{~d}, \mathrm{C}$, $J_{\mathrm{C}-\mathrm{P}}=17.5 \mathrm{~Hz}$, carbene $) .{ }^{31} \mathrm{P}\left\{{ }^{1} \mathrm{H}\right\}$ NMR $\left(\mathrm{CDCl}_{3}\right.$, $T=298 \mathrm{~K}, \delta, \mathrm{ppm}):-66.7 . \mathrm{IR}(\mathrm{KBr}): \nu_{\mathrm{C}=\mathrm{O}}=1709$, $1670 \mathrm{~cm}^{-1}, \nu_{\mathrm{C}-\mathrm{O}}=1242 \mathrm{~cm}^{-1}, 1207 \mathrm{~cm}^{-1}$. Anal. Calcd for $\mathrm{C}_{33} \mathrm{H}_{40} \mathrm{~N}_{7} \mathrm{O}_{10} \mathrm{PPd}(\%)$ : C 47.63, H 4.85, N 11.78. Found (\%): C 47.75, H 4.82, N 11.82.

\subsection{6 | Complex 3c}

Brown microcrystals; yield 92\%. ${ }^{1} \mathrm{H}$ NMR (400 MHz, $\left.\mathrm{CDCl}_{3}, T=298 \mathrm{~K}, \delta, \mathrm{ppm}\right): 3.24$ (s, $\left.3 \mathrm{H}, \mathrm{OCH}_{3}\right), 3.60$ (s, $\left.3 \mathrm{H}, \mathrm{OCH}_{3}\right), 3.68\left(\mathrm{~s}, 3 \mathrm{H}, \mathrm{OCH}_{3}\right), 3.80\left(\mathrm{~s}, 3 \mathrm{H}, \mathrm{OCH}_{3}\right), 3.82$ $\left(\mathrm{s}, 3 \mathrm{H}, \mathrm{NCH}_{3}\right), 4.00\left(\mathrm{~d}, 6 \mathrm{H}, J=2.0 \mathrm{~Hz}, 3 \mathrm{NCH}_{2} \mathrm{P}\right), 4.04$ (s, $\left.3 \mathrm{H}, \mathrm{NCH}_{3}\right), 4.20\left(\mathrm{~s}, 3 \mathrm{H}, \mathrm{NCH}_{3}\right), 4.48\left(\mathrm{~s}, 6 \mathrm{H}, 3 \mathrm{NCH}_{2} \mathrm{~N}\right)$, $5.18\left(\mathrm{~s}, 2 \mathrm{H}, \mathrm{NCH}_{2}\right), 7.32-7.50$ (m, 5H, Ph). $\left.{ }^{13} \mathrm{C}^{1}{ }^{1} \mathrm{H}\right\} \mathrm{NMR}$ $\left(\mathrm{CDCl}_{3}, T=298 \mathrm{~K}, \delta, \mathrm{ppm}\right): 32.0\left(\mathrm{CH}_{3}, \mathrm{NCH}_{3}\right), 37.0$ $\left(\mathrm{CH}_{3}, \mathrm{NCH}_{3}\right), 39.0\left(\mathrm{CH}_{3}, \mathrm{NCH}_{3}\right), 45.3\left(\mathrm{CH}_{2}, \mathrm{NCH}_{2}\right), 50.9$ $\left(\mathrm{CH}_{3}, \mathrm{OCH}_{3}\right), 51.1\left(\mathrm{~d}, \mathrm{CH}_{2}, J_{\mathrm{C}-\mathrm{P}}=10.3 \mathrm{~Hz}, \mathrm{NCH}_{2} \mathrm{P}\right)$, $51.3\left(\mathrm{CH}_{3}, \mathrm{OCH}_{3}\right), 51.4\left(\mathrm{CH}_{3}, \mathrm{OCH}_{3}\right), 51.6\left(\mathrm{CH}_{3}, \mathrm{OCH}_{3}\right)$, $73.1\left(\mathrm{~d}, \mathrm{CH}_{2}, J_{\mathrm{C}-\mathrm{P}}=6.4 \mathrm{~Hz}, \mathrm{NCH}_{2} \mathrm{~N}\right), 110.1\left(\mathrm{C}, \mathrm{C}^{5}\right)$, 128.0-136.2 (Ph), $140.8 \quad\left(\mathrm{C}, \mathrm{C}^{4}\right), \quad 163.6-164.3 \quad(\mathrm{C}$, $\left.\mathrm{COOCH}_{3}\right), \quad 165.4 \quad\left(\mathrm{C}, \quad \mathrm{C}-\mathrm{COOCH}_{3}\right), \quad 168.9 \quad$ (C, $\left.C-\mathrm{COOCH}_{3}\right), 175.1\left(\mathrm{~d}, \mathrm{C}, J_{\mathrm{C}-\mathrm{P}}=5.5 \mathrm{~Hz}, \mathrm{COOCH}_{3}\right)$, $177.3\left(\mathrm{~d}, \mathrm{C}, J_{\mathrm{C}-\mathrm{P}}=5.7 \mathrm{~Hz}, C \mathrm{OOCH}_{3}\right), 186.0\left(\mathrm{~d}, \mathrm{C}, J_{\mathrm{C}-}\right.$
${ }_{\mathrm{P}}=18.7 \mathrm{~Hz}$, carbene $){ }^{31} \mathrm{P}\left\{{ }^{1} \mathrm{H}\right\} \mathrm{NMR}\left(\mathrm{CDCl}_{3}, T=298 \mathrm{~K}\right.$, $\delta$, ppm): -64.8. IR $(\mathrm{KBr}): \nu_{\mathrm{C}=\mathrm{O}}=1710,1672 \mathrm{~cm}^{-1}$, $\nu_{\mathrm{C}-\mathrm{O}}=1243,1207 \mathrm{~cm}^{-1}$. Anal. Calcd for $\mathrm{C}_{33} \mathrm{H}_{40} \mathrm{~N}_{7} \mathrm{O}_{10} \mathrm{PPd}(\%): \mathrm{C} 47.63, \mathrm{H} 4.85, \mathrm{~N}$ 11.78. Found (\%): C 47.78, H 4.92, N 11.86.

\section{8 | Synthesis of mixed NHC-DIC palladacyclopentadienyl complexes (4)}

\subsection{1 | Complex 4a}

In a $50 \mathrm{ml}$ two-necked flask, $43.8 \mathrm{mg}(0.112 \mathrm{mmol})$ of $\left[\mathrm{PdC}_{4}\left(\mathrm{COOCH}_{3}\right)_{4}\right]_{n}$ was dissolved in $5 \mathrm{ml}$ of anhydrous $\mathrm{CH}_{2} \mathrm{Cl}_{2}$ under inert atmosphere (argon). Amounts of $39.4 \mathrm{mg}(0.0560 \mathrm{mmol})$ of complex Aga and $14.7 \mathrm{mg}$ (0.112 mmol) of DIC, suspended in $25 \mathrm{ml}$ of anhydrous $\mathrm{CH}_{2} \mathrm{Cl}_{2}$, were added to the solution of $\left[\mathrm{PdC}_{4}\right.$ $\left.\left(\mathrm{COOCH}_{3}\right)_{4}\right]_{n}$ and precipitation of $\mathrm{AgCl}$ was immediately observed. The mixture was reacted for $48 \mathrm{~h}$ at room temperature and then filtered using a Millipore apparatus. The clear brownish solution was concentrated under vacuum and the title complex precipitated by addition of diethyl ether. The brownish microcrystalline precipitate was filtered off using a Gooch filter, washed with diethyl ether and dried under vacuum. An amount of $73.1 \mathrm{mg}$ (89\% yield) of complex $\mathbf{4 a}$ was obtained.

${ }^{1} \mathrm{H}$ NMR (400 MHz, $\left.\mathrm{CDCl}_{3}, T=298 \mathrm{~K}, \delta, \mathrm{ppm}\right): 2.35$ (s, $\left.6 \mathrm{H}, 2 \mathrm{CH}_{3}{ }^{\mathrm{DIC}}\right), 3.34\left(\mathrm{~s}, 3 \mathrm{H}, \mathrm{OCH}_{3}\right), 3.41\left(\mathrm{~s}, 3 \mathrm{H}, \mathrm{NCH}_{3}\right)$, $3.58\left(\mathrm{~s}, 3 \mathrm{H}, \mathrm{OCH}_{3}\right), 3.61\left(\mathrm{~s}, 3 \mathrm{H}, \mathrm{OCH}_{3}\right), 3.69(\mathrm{~s}, 3 \mathrm{H}$, $\left.\mathrm{OCH}_{3}\right), 3.83\left(\mathrm{~s}, 3 \mathrm{H}, \mathrm{NCH}_{3}\right), 4.14\left(\mathrm{~s}, 3 \mathrm{H}, \mathrm{NCH}_{3}\right), 4.30$ (s, $\left.3 \mathrm{H}, \mathrm{NCH}_{3}\right), 7.12\left(\mathrm{~d}, 2 \mathrm{H}, J=8.1 \mathrm{~Hz}, 2 \mathrm{H}^{\text {meta }}\right), 7.23(\mathrm{t}, 1 \mathrm{H}$, $\left.J=8.1 \mathrm{~Hz}, \mathrm{H}^{\text {para }}\right) .{ }^{13} \mathrm{C}\left\{{ }^{1} \mathrm{H}\right\} \mathrm{NMR}\left(\mathrm{CDCl}_{3}, T=298 \mathrm{~K}, \delta\right.$, ppm): $18.5\left(\mathrm{CH}_{3}, \mathrm{CH}_{3}{ }^{\mathrm{DIC}}\right), 28.6\left(\mathrm{CH}_{3}, \mathrm{NCH}_{3}\right), 32.0\left(\mathrm{CH}_{3}\right.$, $\left.\mathrm{NCH}_{3}\right), 37.1\left(\mathrm{CH}_{3}, \mathrm{NCH}_{3}\right), 39.0\left(\mathrm{CH}_{3}, \mathrm{NCH}_{3}\right), 51.0\left(\mathrm{CH}_{3}\right.$, $\left.\mathrm{OCH}_{3}\right), 51.3\left(\mathrm{CH}_{3}, \mathrm{OCH}_{3}\right), 110.1\left(\mathrm{C}, \mathrm{C}^{5}\right), 128.2-135.1$ $\left(\mathrm{Ph}^{\mathrm{DIC}}\right), 140.6\left(\mathrm{C}, \mathrm{C}^{4}\right), 145.9\left(\mathrm{C}, \mathrm{C}-\mathrm{COOCH}_{3}\right), 147.7(\mathrm{C}$, $\left.\mathrm{C}-\mathrm{COOCH}_{3}\right), 149.0(\mathrm{C}, \mathrm{CN}), 150.5(\mathrm{C}, \mathrm{C}=\mathrm{O}), 153.1(\mathrm{C}$, $\mathrm{C}=\mathrm{O}), 164.3\left(\mathrm{C}, \mathrm{COOCH}_{3}\right), 164.5\left(\mathrm{C}, \mathrm{COOCH}_{3}\right), 164.8$ $\left(\mathrm{C}, \mathrm{C}-\mathrm{COOCH}_{3}\right), 166.5\left(\mathrm{C}, \mathrm{C}-\mathrm{COOCH}_{3}\right), 174.9(\mathrm{C}$, $\left.\mathrm{COOCH}_{3}\right), 175.6\left(\mathrm{C}, \mathrm{COOCH}_{3}\right), 185.8(\mathrm{C}$, carbene). IR $(\mathrm{KBr}): v_{\mathrm{C}=\mathrm{N}}=2176 \mathrm{~cm}^{-1}, v_{\mathrm{C}=\mathrm{O}}=1710,1670 \mathrm{~cm}^{-1}$, $\nu_{\mathrm{C}-\mathrm{O}}=1207 \mathrm{~cm}^{-1}$. Anal. Calcd for $\mathrm{C}_{30} \mathrm{H}_{33} \mathrm{~N}_{5} \mathrm{O}_{10} \mathrm{Pd}(\%)$ : C 49.36, H 4.56, N 9.59. Found (\%): C 49.52, H 4.68, N 9.47.

Derivatives $\mathbf{4 b}$ and $\mathbf{4 c}$ were prepared in a similar way from the appropriate reactants.

\subsection{2 | Complex $4 b$}

Yiellow microcrystals; yield $84 \% .{ }^{1} \mathrm{H}$ NMR (400 MHz, $\left.\mathrm{CDCl}_{3}, T=298 \mathrm{~K}, \delta, \mathrm{ppm}\right): 2.11\left(\mathrm{~s}, 6 \mathrm{H}, 2 \mathrm{CH}_{3}{ }^{\mathrm{DIC}}\right), 3.29$ $\left(\mathrm{s}, 3 \mathrm{H}, \mathrm{OCH}_{3}\right), 3.35\left(\mathrm{~s}, 3 \mathrm{H}, \mathrm{NCH}_{3}\right), 3.56\left(\mathrm{~s}, 3 \mathrm{H}, \mathrm{OCH}_{3}\right)$, $3.66\left(\mathrm{~s}, 3 \mathrm{H}, \mathrm{OCH}_{3}\right), 3.70\left(\mathrm{~s}, 3 \mathrm{H}, \mathrm{OCH}_{3}\right), 3.84(\mathrm{~s}, 3 \mathrm{H}$, 
$\mathrm{NCH}_{3}$ ), 4.33 (s, 3H, $\mathrm{NCH}_{3}$ ), 5.60 and 5.94 (AB system, $2 \mathrm{H}$, $\left.J=14.7 \mathrm{~Hz}, \mathrm{NCH}_{2}\right), 7.04-7.44\left(\mathrm{~m}, 8 \mathrm{H}, \mathrm{Ph}^{\mathrm{DIC}}, \mathrm{Ph}^{\mathrm{Bn}}\right)$. ${ }^{13} \mathrm{C}\left\{{ }^{1} \mathrm{H}\right\}$ NMR $\left(\mathrm{CDCl}_{3}, \mathrm{~T}=298 \mathrm{~K}, \delta, \mathrm{ppm}\right): 18.4\left(\mathrm{CH}_{3}\right.$, $\left.\mathrm{CH}_{3}{ }^{\mathrm{DIC}}\right), 28.7\left(\mathrm{CH}_{3}, \mathrm{NCH}_{3}\right), 32.0\left(\mathrm{CH}_{3}, \mathrm{NCH}_{3}\right), 39.3$ $\left(\mathrm{CH}_{3}, \mathrm{NCH}_{3}\right), 51.0\left(\mathrm{CH}_{3}, \mathrm{OCH}_{3}\right), 51.1\left(\mathrm{CH}_{3}, \mathrm{OCH}_{3}\right), 51.3$ $\left(\mathrm{CH}_{3}, \mathrm{OCH}_{3}\right), 51.4\left(\mathrm{CH}_{3}, \mathrm{OCH}_{3}\right), 53.1\left(\mathrm{CH}_{2}, \mathrm{NCH}_{2}\right)$, $109.7\left(\mathrm{C}, \mathrm{C}^{5}\right), 128.0-135.9(\mathrm{Ph}), 140.7\left(\mathrm{C}, \mathrm{C}^{4}\right), 145.7(\mathrm{C}$, $\left.\mathrm{C}-\mathrm{COOCH}_{3}\right), 148.2\left(\mathrm{C}, \mathrm{C}-\mathrm{COOCH}_{3}\right), 149.1(\mathrm{C}, \mathrm{CN})$, $150.5(\mathrm{C}, \mathrm{C}=\mathrm{O}), 152.8(\mathrm{C}, \mathrm{C}=\mathrm{O}), 163.7\left(\mathrm{C}, \mathrm{COOCH}_{3}\right)$, $164.6\left(\mathrm{C}, \mathrm{COOCH}_{3}\right), 164.8\left(\mathrm{C}, \mathrm{C}-\mathrm{COOCH}_{3}\right), 166.9(\mathrm{C}$, $\left.\mathrm{C}-\mathrm{COOCH}_{3}\right), 174.9\left(\mathrm{C}, \mathrm{COOCH}_{3}\right), 175.5\left(\mathrm{C}, \mathrm{COOCH}_{3}\right)$, 187.4 (C, carbene). IR (KBr): $v_{\mathrm{C}=\mathrm{N}}=2177 \mathrm{~cm}^{-1}$, $v_{\mathrm{C}=\mathrm{O}}=1710,1670 \mathrm{~cm}^{-1}, v_{\mathrm{C}-\mathrm{O}}=1208 \mathrm{~cm}^{-1}$. Anal. Calcd for $\mathrm{C}_{36} \mathrm{H}_{37} \mathrm{~N}_{5} \mathrm{O}_{10} \mathrm{Pd}(\%)$ : C 53.64, $\mathrm{H}$ 4.63, N 8.69. Found (\%): C 53.73, H 4.78, N 8.61.

\subsection{3 | Complex 4c}

Yiellow microcrystals; yield $87 \% .{ }^{1} \mathrm{H}$ NMR (400 MHz, $\left.\mathrm{CDCl}_{3}, T=298 \mathrm{~K}, \delta, \mathrm{ppm}\right): 2.35$ (s, $\left.6 \mathrm{H}, 2 \mathrm{CH}_{3}{ }^{\mathrm{DIC}}\right), 3.32$ $\left(\mathrm{s}, 3 \mathrm{H}, \mathrm{OCH}_{3}\right), 3.57\left(\mathrm{~s}, 3 \mathrm{H}, \mathrm{NCH}_{3}\right), 3.65\left(\mathrm{~s}, 3 \mathrm{H}, \mathrm{OCH}_{3}\right)$, $3.69\left(\mathrm{~s}, 3 \mathrm{H}, \mathrm{OCH}_{3}\right), 3.81\left(\mathrm{~s}, 3 \mathrm{H}, \mathrm{OCH}_{3}\right), 4.15(\mathrm{~s}, 3 \mathrm{H}$, $\left.\mathrm{NCH}_{3}\right), 4.28\left(\mathrm{~s}, 3 \mathrm{H}, \mathrm{NCH}_{3}\right), 5.14$ and $5.20(\mathrm{AB}$ system, $\left.2 \mathrm{H}, J=13.8 \mathrm{~Hz}, \mathrm{NCH}_{2}\right), 7.10-7.48\left(\mathrm{~m}, 8 \mathrm{H}, \mathrm{Ph}^{\mathrm{DIC}}, \mathrm{Ph}^{\mathrm{Bn}}\right)$. ${ }^{13} \mathrm{C}\left\{{ }^{1} \mathrm{H}\right\}$ NMR $\left(\mathrm{CDCl}_{3}, \mathrm{~T}=298 \mathrm{~K}, \delta, \mathrm{ppm}\right): 18.6\left(\mathrm{CH}_{3}\right.$, $\left.\mathrm{CH}_{3}{ }^{\mathrm{DIC}}\right), 32.0\left(\mathrm{CH}_{3}, \mathrm{NCH}_{3}\right), 37.1\left(\mathrm{CH}_{3}, \mathrm{NCH}_{3}\right), 39.0$ $\left(\mathrm{CH}_{3}, \mathrm{NCH}_{3}\right), 45.2\left(\mathrm{CH}_{2}, \mathrm{NCH}_{2}\right), 51.0\left(\mathrm{CH}_{3}, \mathrm{OCH}_{3}\right), 51.3$ $\left(\mathrm{CH}_{3}, \mathrm{OCH}_{3}\right), \quad 51.4 \quad\left(\mathrm{CH}_{3}, \mathrm{OCH}_{3}\right), 110.2\left(\mathrm{C}, \mathrm{C}^{5}\right)$, 128.0-136.3 (Ph), $140.7\left(\mathrm{C}, \mathrm{C}^{4}\right), 145.8\left(\mathrm{C}, \mathrm{C}-\mathrm{COOCH}_{3}\right)$, $147.7\left(\mathrm{C}, \mathrm{C}-\mathrm{COOCH}_{3}\right), 149.0(\mathrm{C}, \mathrm{CN}), 150.4(\mathrm{C}, \mathrm{C}=\mathrm{O})$, $153.0(\mathrm{C}, \mathrm{C}=\mathrm{O}), 164.2\left(\mathrm{C}, \mathrm{COOCH}_{3}\right), 164.5\left(\mathrm{C}, \mathrm{COOCH}_{3}\right)$, $164.8\left(\mathrm{C}, \mathrm{C}-\mathrm{COOCH}_{3}\right), 166.4\left(\mathrm{C}, \mathrm{C}-\mathrm{COOCH}_{3}\right), 174.9(\mathrm{C}$, $\left.\mathrm{COOCH}_{3}\right), 175.6\left(\mathrm{C}, \mathrm{COOCH}_{3}\right), 186.0$ (C, carbene). IR $(\mathrm{KBr}): v_{\mathrm{C}=\mathrm{N}}=2178 \mathrm{~cm}^{-1}, v_{\mathrm{C}=\mathrm{O}}=1710,1675 \mathrm{~cm}^{-1}$, $v_{\mathrm{C}-\mathrm{O}}=1205 \mathrm{~cm}^{-1}$. Anal. Calcd for $\mathrm{C}_{36} \mathrm{H}_{37} \mathrm{~N}_{5} \mathrm{O}_{10} \mathrm{Pd}(\%)$ : C 53.64, H 4.63, N 8.69. Found (\%): C 53.51, H 4.69, N 8.72.

\subsection{Cell growth evaluation}

Cell viability inhibition assays were carried out using human ovarian A2780 (cisplatin-sensitive) and A2780cis (cisplatin-resistant) cancer cells and human lung fibroblast MRC-5 normal cells. The cells were obtained from ATCC (Manassas, VA). The A2780 cell lines were maintained in RPMI 1640, supplemented with $10 \%$ foetal bovine serum, penicillin/streptomycin (100 $\mathrm{U} \mathrm{ml}^{-1}$ ) and glutamine ( $2 \mathrm{mM}$ ) (complete medium); to maintain the resistance, $1 \mu \mathrm{M}$ cisplatin was routinely added to the A2780cis cells. The $\mathrm{pH}$ of the medium was 7.2 and the incubation was performed at $37^{\circ} \mathrm{C}$ in a $5 \% \mathrm{CO}_{2}$ atmosphere. Adherent cells were routinely used at $70 \%$ of confluence and passaged every 3 days by treatment with $0.25 \%$ trypsin-EDTA (Sigma-Aldrich, St Louis, MO, USA).

The MRC- 5 cells were maintained in Eagle's minimum essential medium, non-essential amino acids, $2 \mathrm{mM}$ L-glutamine, $1 \mathrm{mM}$ sodium pyruvate and $1500 \mathrm{mg}^{-1}$ sodium bicarbonate. To make the complete growth medium, the following components were added to the base medium: foetal bovine serum to a final concentration of $10 \%$ and penicillin/streptomycin $\left(100 \mathrm{U} \mathrm{ml}^{-1}\right)$.

All the derivatives were added at serial dilutions and incubated in cell cultures: $50 \mathrm{mM}$ stock solutions of each complex were prepared using pure DMSO, and the working solutions $(5 \mathrm{mM}, 500 \mu \mathrm{M}$ and $50 \mu \mathrm{M})$ were obtained by successive dilution in EtOH. The water-soluble derivatives 3a-c were assayed also using aqueous solutions, showing $\mathrm{IC}_{50}$ values comparable to those obtained with DMSO-EtOH solutions. After $72 \mathrm{~h}$ of treatment, cells were washed with PBS $1 \times$ and detached with trypsin. Cells were then suspended in physiological solution and counted with a Z2 Coulter Counter (Coulter Electronics, Hialeah, FL, USA). The cell number per millilitre was determined as $\mathrm{IC}_{50}$ after 3 days of culture, when untreated cells were in log phase of cell growth. ${ }^{[1,25]}$ Cisplatin, solubilized in sterile water, was employed as positive control and untreated cells were placed in every plate as negative control. The cells were exposed to the compounds in $1000 \mu \mathrm{l}$ total volume.

\subsection{0 | Apoptosis assays}

Annexin V and dead cell assays on A2780 and A2780cis cells, untreated and treated for $72 \mathrm{~h}$ with increasing doses of analysed derivatives, were performed with a Muse cell analyser (Millipore, Billerica, MA, USA), according to the instructions supplied by the manufacturer. This procedure utilizes Annexin V to detect phosphatidylserine on the external membrane of apoptotic cells. Moreover, a dead cell marker is also utilized in the same kit as indicator of cell membrane structural integrity. Cells were washed with sterile PBS $1 \times$, tripsinized, resuspended in the original medium and diluted (1:1) with one-step addition of Muse Annexin V and Dead Cell reagent. After 20 min of incubation at room temperature in the dark, samples were analysed. ${ }^{[11]}$ Data from prepared samples were acquired and recorded utilizing the Annexin V and Dead Cell Software Module (Millipore, Billerica, MA, USA).

\section{ACKNOWLEDGEMENTS}

This work was supported by the University of Ferrara (grant FAR 2017 to I.L. and R.G.). R.G. is funded by AIRC 
(Associazione Italiana Ricerca sul Cancro) and by CIB (Consorzio Interuniversitario per le Biotecnologie).

\section{ORCID}

Luciano Canovese (D) https://orcid.org/0000-0001-7370-3127 Nicola Demitri (D) https://orcid.org/0000-0003-0288-3233

Fabiano Visentin (10) https://orcid.org/0000-0001-9513-1182

\section{REFERENCES}

[1] a) B. Rosenberg, L. van Camp, T. Krigas, Nature 1965, 205, 698; b) B. Rosenberg, in Cisplatin, Chemistry and Biochemistry of a Leading Anticancer Drug, (Ed: S. J. Lippert), Wiley-VCH, Weinheim 1999.

[2] a) M. A. Fuentes, C. Alonso, J. M. Perez, Chem. Rev. 2003, 103, 645; b) Y. Jung, S. J. Lippard, Chem. Rev. 2007, 107, 1387; c) J. Reedijk, Eur. J. Inorg. Chem. 2009, 2009, 1303.

[3] N. J. Wheate, S. Walker, G. E. Craig, R. Oun, Dalton Trans. 2010, 39, 8113.

[4] a) Z. J. Guo, P. J. Sadler, Adv. Inorg. Chem. 2000, 49, 183; b) E. Alessio, Bioinorganic Medicinal Chemistry, WILEY-VCH, Weinheim 2008; c) M. A. Jakupec, M. Galanski, V. B. Arion, C. G. Hartinger, B. K. Keppler, Dalton Trans. 2008, 183; d) F. Arnesano, G. Natile, Pure Appl. Chem. 2008, 80, 2715; e) J. C. Dabrowiak, Metals in Medicine, John Wiley \& Sons, Ltd, Chichester 2009; f) T. Gianferrara, I. Bratsos, E. Alessio, Dalton Trans. 2009, 7588; g) A. Casini, C. G. Hartinger, A. A. Nazarov, P. J. Dyson, Top Organometal Chem 2010, 32, 57; h) P. Zhang, P. J. Sadler, J. Organometal. Chem. 2017, 839, 5.

[5] (a) A. R. Kapdi, I. J. S. Fairlamb, Chem. Soc. Rev. 2014, 43, 4751; b) M. A. Jakupec, M. Galanski, V. B. Arion, C. G. Hartinger, B. K. Keppler, Dalton Trans. 2008, 183; c) C. Sanchez-Cano, M. J. Hannon, Dalton Trans. 2009, 10702; d) I. Ott, Coord. Chem. Rev. 2009, 253, 1670; e) C. Gabbiani, L. Messori, Anti-Cancer Agents Med. Chem. 2011, 11, 929; f) A. Bindoli, M. P. Rigobello, G. Scutari, C. Gabbiani, A. Casini, L. Messori, Coord. Chem. Rev. 2009, 253, 1692; g) A. Casini, L. Messori, Curr. Top. Med. Chem. 2011, 11, 2647.

[6] E. Alessio, Bioinorganic Medicinal Chemistry, Wiley-VCH, Weinheim 2011.

[7] M. D. Coskun, F. Ari, A. Y. Oral, M. Sarimahmut, H. M. Kutlu, V. T. Yilmaz, E. Ulukaya, Bioorg. Med. Chem. 2013, 21, 4698.

[8] a)M. M. Shoukry, A. A. Shoukry, M. N. Hafez, J. Coord. Chem. 2010, 63, 652. b)H. Hohamann, R. Van Eldik, Inorg. Chim. Acta 1990, 174, 87. c)H. Hohamann, H. Suvachittanont, R. van Eldik, Inorg. Chim. Acta 1990, 177, 5.

[9] a) S. Ray, R. Mohan, J. K. Singh, M. K. Samantaray, M. M. Shaikh, D. Panda, P. Ghosh, J. Am. Chem. Soc. 2007, 129, 15042; b) N. Cutillas, G. S. Yellol, C. de Haro, C. Vicente, V. Rodríguez, J. Ruiz, Coord. Chem. Rev. 2013, 257, 2784; c) S. Medici, M. Peana, V. M. Nurchi, J. I. Lachowicz, G. Crisponi, M. A. Zoroddua, Coord. Chem. Rev. 2015, 284, 329; d) S. Y. Hussaini, R. A. Haque, M. R. Razali, J. Organometal. Chem. 2019, 17, 91.
[10] a) A. Kascatan-Nebioglu, M. J. Panzner, J. C. Garrison, C. A. Tessier, W. J. Youngs, Organometallics 2004, 23, 1928; b) J. Schütz, W. A. Herrmann, J. Organometal. Chem. 2004, 689, 2995; c) A. Kascatan-Nebioglu, A. Melaiye, K. Hindi, S. Durmus, M. J. Panzner, L. A. Hogue, R. J. Mallett, C. E. Hovis, M. Coughenour, S. D. Crosby, A. Milsted, D. L. Ely, C. A. Tessier, C. L. Cannon, W. J. Youngs, J. Med. Chem. 2006, 49, 6811; d) F.-T. Luo, H.-K. Lo, J. Organometal. Chem. 2011, 696, 1262; e) A. Makhloufi, W. Frank, C. Ganter, Organometallics 2012, 31, 7272; f) A. Monney, M. Albrecht, Coord. Chem. Rev. 2013, 257, 2420; g) S. E. Flowers, B. M. Cossairt, Organometallics 2014, 33, 4341; h) J. Zhang, J. K. Muenzner, M. A. Abu el Maaty, B. Karge, R. Schobert, S. Wölf, I. Ott, Dalton Trans. 2016, 45, 13161; i) E. Mohammadi, B. Movassagh, J. Organometal. Chem. 2016, 822, 62; j) A. Szadkowska, S. Staszko, E. Zaorska, R. Pawlowski, RSC Adv. 2016, 6, 44248.

[11] a) T. Scattolin, I. Caligiuri, L. Canovese, N. Demitri, R. Gambari, I. Lampronti, F. Rizzolio, C. Santo, F. Visentin, Dalton Trans. 2018, 47, 13616; b) T. Scattolin, L. Canovese, F. Visentin, S. Paganelli, P. Canton, N. Demitri, Appl. Organometal. Chem. 2018, 32, e4034.

[12] a) W. A. Hermann, Angew. Chem. Int. Ed. 2002, 41, 1290; b) L. Cavallo, A. Correa, C. Costabile, H. Jacobsen, J. Organometal. Chem. 2005, 690, 5407; c) S. Díez-González, S. P. Nolan, Coord. Chem. Rev. 2007, 251, 874; d) P. de Frémont, N. Marion, S. P. Nolan, Coord. Chem. Rev. 2009, 253, 862; e) T.-H. Fong, C.-N. Lok, C. Y.-S. Chung, Y.-M. E. Fong, P.-K. Chow, P.-K. Wan, C.-M. Che, Angew. Chem. Int. Ed. 2016, 55, 11935.

[13] a) J. G. Cropp, Am. J. Med. 1996, 100(1A), 195; b) M. Teyssot, A. Jarrousse, M. Manin, A. Chevry, S. Roche, F. Norre, C. Beaudoin, L. Morel, D. Boyer, R. Mahioue, A. Gautier, Dalton Trans. 2009, 6894; c) A. John, P. Ghosh, Dalton Trans. 2010, 39, 7183; d) S. B. Aher, P. N. Muskawar, K. Thenmozhi, P. R. Bhagat, Eur. J. Med. Chem. 2014, 81, 408.

[14] a) T. A. K. Al-Allaf, L. J. Rashan, Eur. J. Med. Chem. 1998, 33, 817; b) A. Valentini, F. Conforti, A. Crispini, A. De Martino, R. Condello, C. Stellitano, G. Rotillo, M. Ghedini, G. Federici, S. Bernardini, D. Pucci, J. Med. Chem. 2009, 52, 484; c) A. Monney, M. Albrecht, Coord. Chem. Rev. 2013, 257, 2420; d) M. Tanaka, H. Kataoka, S. Yano, H. Ohi, K. Kawamoto, T. Shibahara, T. Mizoshita, Y. Mori, S. Tanida, T. Kamiya, T. Joh, BMC Cancer 2013, 13, 327.

[15] a) L. Canovese, F. Visentin, T. Scattolin, C. Santo, V. Bertolasi, J. Organometal. Chem. 2016, 808, 48; b) L. Canovese, F. Visentin, T. Scattolin, C. Santo, V. Bertolasi, Polyhedron 2016, 113, 25; c) T. Scattolin, F. Visentin, C. Santo, V. Bertolasi, L. Canovese, Dalton Trans. 2016, 45, 11560; d) L. Canovese, F. Visentin, T. Scattolin, C. Santo, V. Bertolasi, Dalton Trans. 2015, 44, 15049; e) L. Canovese, C. Santo, T. Scattolin, F. Visentin, V. Bertolasi, J. Organometal. Chem. 2015, 794, 288; f) F. Visentin, C. Santo, T. Scattolin, N. Demitri, L. Canovese, Dalton Trans. 2017, 46, 10399.

[16] a) D. A. Krogstad, J. Cho, A. J. DeBoer, J. A. Klitzke, W. R. Sanow, H. A. Williams, J. A. Halfen, Inorg. Chim. Acta 2006, 359, 136; b) E. Vergara, S. Miranda, F. Mohr, E. Cerrada, E. R. T. Tiekink, P. Romero, A. Mendía, M. Laguna, Eur. J. Inorg. Chem. 2007, 2007, 2926; c) J. Spencer, A. Casini, O. Zava, R. P. Rathnam, S. K. Velhanda, M. Pfeffer, S. K. Callear, M. B. 
Hursthouseand, P. Dyson, Dalton Trans. 2009, 10731; d) J. Lasri, M. J. Fernández Rodríguez, M. F. C. Guedes da Silva, P. Smolenski, M. N. Kopylovich, J. J. R. Fraústo da Silva, A. J. L. Pombeiro, J. Organometal. Chem. 2011, 696, 3513; e) M. Carreira, R. Calvo-Sanjuan, M. Sanauí, I. Marzo, M. Contel, Organometallics 2012, 31, 5772; f) E. Guerrero, S. Miranda, S. Luüttenberg, N. Froöhlich, J. Koenen, F. Mohr, E. Cerrada, M. Laguna, A. Mendía, Inorg. Chem. 2013, 52, 6635; g) J. Braddock-Wilking, S. Acharya, N. P. Rath, Polyhedron 2014, 79, 16; h) V. Ferretti, M. Fogagnolo, A. Marchi, L. Marvelli, F. Sforza, P. Bergamini, Inorg. Chem. 2014, 53(10), 4881.

[17] P. de Fremont, N. M. Scott, E. D. Stevens, T. Ramnial, O. C. Lightbody, C. L. B. Macdonald, J. A. C. Clyburne, C. D. Abernethy, S. P. Nolan, Organometallics 2005, 24, 6301.

[18] K. Moseley, P. M. Maitlis, J. Chem. Soc. Dalton Trans. 1974, 169.

[19] M. J. Frisch, G. W. Trucks, H. B. Schlegel, G. E. Scuseria, M. A. Robb, J. R. Cheeseman, G. Scalmani, V. Barone, B. Mennucci, G. A. Petersson, H. Nakatsuji, M. Caricato, X. Li, H. P. Hratchian, A. F. Izmaylov, J. Bloino, G. Zheng, J. L. Sonnenberg, M. Hada, M. Ehara, K. Toyota, R. Fukuda, J. Hasegawa, M. Ishida, T. Nakajima, Y. Honda, O. Kitao, H. Nakai, T. Vreven, J. A. Montgomery Jr., J. E. Peralta, F. Ogliaro, M. Bearpark, J. J. Heyd, E. Brothers, K. N. Kudin, V. N. Staroverov, R. Kobayashi, J. Normand, K. Raghavachari, A. Rendell, J. C. Burant, S. S. Iyengar, J. Tomasi, M. Cossi, N. Rega, J. M. Millam, M. Klene, J. E. Knox, J. B. Cross, V. Bakken, C. Adamo, J. Jaramillo, R. Gomperts, R. E. Stratmann, O. Yazyev, A. J. Austin, R. Cammi, C. Pomelli, J. W. Ochterski, R. L. Martin, K. Morokuma, V. G. Zakrzewski, G. A. Voth, P. Salvador, J. J. Dannenberg, S. Dapprich, A. D. Daniels, Ö. Farkas, J. B. Foresman, J. V. Ortiz, J. Cioslowski, D. J. Fox, Gaussian 09, Gaussian Inc., Wallingford, CT, 2009.

[20] L. Canovese, F. Visentin, T. Scattolin, C. Santo, V. Bertolasi, Polyhedron 2018, 144, 131.

[21] L. Farrugia, J. Appl. Crystallogr. 2012, 45(4), 849.

[22] Among the four reactions hypothesized when the synthesis of the mixed complexes $\mathbf{4}$ is taken into consideration, the formation of the bis-substituted isocyanide species should be the fastest one (reaction 1). Afterwards, the bis-isocyanide species reacts with the silver carbene complex to give the mixed species 4 which was detected in solution at the very beginning of the reaction (reaction 2). The unreacted silver carbene complex concomitantly attacks PdCy to give the bis-carbene palladium species (reaction 3 ). In order to have all the species in solution, reactions 2 and 3 might be almost isochronous whereas reaction 4 (the combination of the bis-carbene and the bisisocyanine palladium complexes) giving the thermodynamically stable complexes $\mathbf{4}$ must be considerably slower than all the others.

[23] A. Romerosa, J. Suarez-Varela, M. A. Hidalgo, J. C. Avila-Roson, E. Colacio, Inorg. Chem. 1997, 36, 3784.

[24] L. Canovese, F. Visentin, C. Levi, C. Santo, V. Bertolasi, Inorg. Chim. Acta 2011, 378, 239.

[25] P. Bergamini, L. Marvelli, V. Ferretti, C. Gemmo, R. Gambari, Y. Hushcha, I. Lampronti, Dalton Trans. 2016, 45, 10752.

[26] K. M. Henkels, J. J. Turchi, Cancer Res. 1999, 59, 3077.

[27] S. Dasari, P. B. Tchounwou, Eur. J. Pharmacol. 2014, 740, 364.

[28] C. Blanc, Q. L. Deveraux, S. Krajewsk, R. U. Jänicke, A. G. Porter, J. C. Reed, R. Jaggi, A. Marti, Cancer Res. 2000, 60, 4386.

[29] Z. Ai, S. Qiu, Z. Fan, Cancer Lett. 2016, 373, 36.

[30] A. Lausi, M. Polentarutti, S. Onesti, J. R. Plaisier, E. Busetto, G. Bais, L. Barba, A. Cassetta, G. Campi, D. Lamba, A. Pifferi, S. C. Mande, D. D. Sharma, S. M. Sharma, G. Paolucci, Eur. Phys. J. Plus 2015, 130(43), 1.

[31] W. Kabsch, Acta Crystallogr. D 2010, 66(2), 125.

[32] G. M. Sheldrick, Acta Crystallogr. A 2015, 71, 3.

[33] A. Spek, Acta Crystallogr. D 2009, 65(2), 148.

[34] G. M. Sheldrick, Acta Crystallogr. C 2015, 71, 3.

[35] P. Emsley, B. Lohkamp, W. Scott, K. Cowtan, Acta Crystallogr. D 2010, 66, 486.

\section{SUPPORTING INFORMATION}

Additional supporting information may be found online in the Supporting Information section at the end of the article.

How to cite this article: Scattolin $\mathrm{T}$, Giust $\mathrm{S}$, Bergamini $\mathrm{P}$, et al. Palladacyclopentadienyl complexes bearing purine-based $\mathrm{N}$-heterocyclic carbenes: A new class of promising antiproliferative agents against human ovarian cancer. Appl Organometal Chem. 2019;33:e4902. https://doi.org/ 10.1002/aoc.4902 